\title{
A Systematic Review of the Anticancer Properties of Compounds Isolated from Licorice (Gancao)
}

Authors

Affiliations
Zheng-Hai Tang ${ }^{1}$, Ting Li ${ }^{1}$, Yun-Guang Tong ${ }^{2}$, Xiao-Jia Chen ${ }^{1}$, Xiu-Ping Chen ${ }^{1}$, Yi-Tao Wang ${ }^{1}$, Jin-Jian Lu ${ }^{1}$

${ }^{1}$ State Key Laboratory of Quality Research in Chinese Medicine, Institute of Chinese Medical Sciences, University of Macau, Macao, China

2 Department of Medicine, Cedars-Sinai Medical Center, University of California at Los Angeles School of Medicine, Los Angeles, CA, USA

\author{
Key words \\ - Glycyrrhiza glabra \\ - Leguminosae \\ - licorice \\ - anticancer \\ - mechanism \\ - triterpenoids \\ - flavonoids
}

received April 28, 2015

revised August 14, 2015

accepted October 16, 2015

\section{Bibliography}

DOI http://dx.doi.org/

10.1055/s-0035-1558227

Planta Med 2015; 81:

1670-1687 (c) Georg Thieme

Verlag KG Stuttgart · New York .

ISSN 0032-0943

\section{Correspondence}

Dr. Jin-Jian Lu

State Key Laboratory of Quality Research in Chinese Medicine Institute of Chinese Medical

Sciences

University of Macau

Avenida da Universidade

Taipa, Macao 999078

China

Phone: +85388224674

Fax: +85328841358

jinjianlu@umac.mo

\section{Abstract \\ $\nabla$}

Licorice (Gancao in Chinese) has been used worldwide as a botanical source in medicine and as a sweetening agent in food products for thousands of years. Triterpene saponins and flavonoids are its main ingredients that exhibit a variety of biological activities, including hepatoprotective, antiulcer, anti-inflammatory, antiviral and anticancer effects among others. This review attempts to summarize the current knowledge on the anticancer properties and mechanisms of the compounds isolated from licorice and obtain new insights for further research and development of licorice. A broad spectrum of in vitro and in vivo studies have recently demonstrated that the mixed extracts and purified compounds from licorice exhibit evident anticancer properties by inhibition of proliferation, induction of cell cycle arrest, apoptosis, autophagy, differentiation, suppression of metastasis, angiogenesis, and sensitization of chemotherapy or radiotherapy. A combined treatment of licorice compounds and clinical chemotherapy drugs remarkably enhances anticancer effects and reduces the side effects of chemotherapeutics. Furthermore, glycyrrhizic acid and glycyrrhetinic acid in licorice have been indicated to present obvious liver-targeting effects in targeted drug delivery systems for hepatocellular carcinoma treatment.

\section{Abbreviations}

$\nabla$

20-HETE: 20-hydroxyeicosatetraenoic acid

70\% EEL: $70 \%$ ethanol (volume, $\mathrm{CH}_{3} \mathrm{CH}_{3} \mathrm{OH}$ : $\mathrm{H}_{2} \mathrm{O}=70: 30$ ) extracts of licorice

70\% MEL: 70\% methanol (volume, $\mathrm{CH}_{3} \mathrm{OH}$ : $\mathrm{H}_{2} \mathrm{O}=70: 30$ ) extracts of licorice

80\% EEL: $80 \%$ ethanol (volume, $\mathrm{CH}_{3} \mathrm{CH}_{3} \mathrm{OH}$ : $\mathrm{H}_{2} \mathrm{O}=80: 20$ ) extracts of licorice

AOM: azoxymethane
AP-1: $\quad$ activator protein 1

$\beta$-hydroxy-DHP:

1-(2,4-dihydroxyphenyl)-3-hydroxy-

3-(4'-hydroxyphenyl) 1-propanone

CDK: $\quad$ cyclin-dependent kinase

COX-2: cyclooxygenases-2

CP: $\quad$ cyclophosphamide

CYP19: $\quad$ cytochrome P450 19

DMBA: dimethylbenz[a]anthracene

DR4: death receptor 4

DSS: dextran sulfate sodium

EAT: Ehrlich ascites tumor

ER: endoplasmic reticulum

ERK: extracellular regulated protein kinases

FasL: $\quad$ Fas ligand

GA: glycyrrhetinic acid

GBD: glabridin

GL: $\quad$ glycyrrhizic acid

GLY: glycyrol

GSH: glutathione hormone

HCC: hepatocellular carcinoma

HEEL: hexane/ethanol extraction of licorice

HMGB1: high-mobility group box 1

HUVECs: human umbilical vein endothelial cells

i.g.: intragastric administration

i. m.: intramuscular injection

i.p.: intraperitoneal injection

i.t.: intratumor injection

i.v.: intravenous injection

IAA: isoangustone A

ICAM: intercellular adhesion molecule

IL: interleukin

ISLG: isoliquiritigenin

ISLT: isoliquiritin

JNK: c-Jun N-terminal kinase

LCA: licochalcone A

LCB: licochalcone $B$

LCE: licochalcone $\mathrm{E}$

LCM: licocoumarone

LG: liquiritigenin

LRD: licoricidin

LT: liquiritin 
MMP:

MMP-2:

MMP-9:

mTOR:

MVD:

NAT:

NF- $k B$ :

NSCLC:

ODC:

p.o.:

PARP:

PCNA:

$\mathrm{PGE}_{2}$ :

PI3 K: mitochondrial membrane potential

matrix metalloproteinase-2

matrix metalloproteinase- 9

mammalian target of rapamycin

microvessel density

$\mathrm{N}$-acetyltransferase

nuclear factor- $k \mathrm{~B}$

non small cell lung carcinoma

ornithine decarboxylase

per os

poly(ADP-ribose)-polymerase

proliferative cell nuclear antigen

prostaglandin $\mathrm{E}_{2}$

phosphoinositide-3 kinase
PKC: $\quad$ protein kinase $\mathrm{C}$

ROS: $\quad$ reactive oxygen species

S.c.: subcutaneous injection

STAT3: $\quad$ signal transducer and activator of transcription 3

TCM: $\quad$ traditional Chinese medicine

TDDS: $\quad$ target drug delivery systems

TNF- $\alpha$ : $\quad$ tumor necrosis factor- $\alpha$

Top I: $\quad$ topoisomerase I

TPA: 12-0-tetradecanoylphorbol 13-acetate

uPA: urokinase-type plasminogen activator

UVB: $\quad$ ultraviolet radiation b

VCAM: vascular cell adhesion molecule

VEGF: vascular endothelial growth factor

VEGFR-2: vascular endothelial growth factor kinase receptor-2

\section{Introduction}

Licorice (Glycyrrhiza in botany, Gancao in Chinese), a perennial herb that extensively grows wild in China, Japan, Russia, Spain, and India, is one of the best-known and most frequently used herbal medicines worldwide [1]. In China, licorice was first recorded in Sheng Nong's herbal classic (Sheng Nong Ben Cao Jing in Chinese), the earliest TCM code, and belongs to "top-grade" herbs (herbs with the lowest side effects or nontoxic usefulness for health care) [2]. Licorice has been subsequently recorded in numerous classic TCM writings and famous prescriptions, such as in one of the earliest TCM books, Treatise on Exogenous Febrile Disease (Shang Han Lun in Chinese), and 70\% of prescriptions have included licorice [3]. In Japan, GL (one of the main compounds from licorice) preparation (Stronger Neo-Minophagen C) has been clinically used as an antihepatitis and antiallergic agent for more than 60 years [4]. Licorice is traditionally used to improve health, lengthen life span, and cure coughs or stomachaches [5].

At present, more than 400 compounds have been isolated from licorice and demonstrated a variety of pharmacological activities, such as anticancer, anti-inflammatory, antiviral, hepatoprotective, expectorant, and memory enhancing activity [6-9]. The triterpene saponins of licorice, especially GL (about $1.84 \%$ to $9.82 \%$ of licorice, depending on the sources and methods of extraction), are the major constituents and bioactive ingredients of licorice, and more than 18 saponins have been isolated from licorice [912]. Flavonoids (about $1.78 \%$ to $4.82 \%$ of licorice, depending on the sources and methods of extraction) are the other main bioactive compounds from licorice, and more than 300 flavonoid compounds have been identified, including LT, ISLT, LG, ISLG, LCA, and GBD $[9,11,13,14]$. In the 2010 edition of the Chinese Pharmacopoeia, GL and LT are selected as the biomarkers for licorice, and GL and LT content should exceed $2 \%$ and $0.5 \%$, respectively [15]. In addition, a series of polyphenols and polysaccharides obtained from licorice have indicated remarkable bioactivity, such as anticancer and immunopotentiating effects [16-18]. The pharmacological effects of licorice, including anti-inflammatory, antiviral, and hepatoprotective effects, were documented in 2008 [6]. However, in recent years, more compounds, especially flavonoids, have been isolated and identified from licorice and have been demonstrated to possess evident anticancer properties both in vitro and in vivo. Therefore, reviewing and summarizing the anticancer effects and mechanisms of mixtures and purified compounds from licorice is necessary to better understand the anticancer properties of licorice and to provide data that may be useful for future anticancer research on this herb.

\section{Mixtures from Licorice \\ $\nabla$}

The mixed extracts of licorice can generally be acquired using aqueous or organic solutions. Aqueous solutions are mainly used to isolate crude extracts, whereas organic solvents, including methanol, ethanol, trichloromethane, and hexane, are utilized to obtain purified compounds. At present, several mixtures from licorice have been demonstrated to possess anticancer properties both in vitro and in vivo by inhibition of proliferation and induction of cell cycle arrest, apoptosis, and autophagy.

\section{Inhibition of proliferation}

Trichloromethane, hexane, ethyl acetate, and 70\% MEL inhibit the proliferation of human breast cancer cell MCF7 in concentrationand time-dependent manners [19]. The 70\% MEL also inhibits the cell proliferation of the hepatocellular carcinoma cell HepG2 [20] and human monoblastic leukemia cell U-937 [21] in a concentration-dependent manner. The 70\% EEL shows concentration- and time-dependent cytotoxicity to human breast cancer cell MDA-MB-231 [22] and human prostate cancer cell LNCaP [23]. In human prostate cancer cell DU 145 and human colon cancer cell HT-29, the ethanol extracts of roasted licorice exhibit considerably higher cytotoxicity than that of the ethanol extract of unroasted licorice, and the active compound of the ethanol extracts of roasted licorice is LCA [24]. Besides, the purified fraction (diethyl ether, chloroform, and water fraction from the EEL) exhibits higher proliferative inhibition on MCF7, human stomach adenocarcinoma cell AGS, and human hepatocellular carcinoma cell Hep3B and less cytotoxicity to human normal hepatic cell WRL-68 compared with the EEL [25].

\section{Induction of cell cycle arrest}

The $80 \%$ EEL induces G1 cell cycle arrest in MCF7 by increasing the expression of p53 and p21 proteins and decreasing cyclin E and CDK2 protein expressions [26]. The HEEL also induces G1 phase arrest by the reduction of the protein expression of cyclin A, cyclin D1, CDK2, and CDK4 in DU 145 and murine mammary cancer cell $4 \mathrm{~T} 1$. A further study also indicates that the active compound in HEEL may be IAA [27]. In addition, G2/M cell cycle arrest in LNCaP and human breast cancer T47D cells is observed with $70 \%$ EEL and EEL treatment, respectively $[23,28]$. 


\section{Induction of apoptosis}

The EEL induces apoptosis in MCF7 cells with the activation of Bax, PARP, and caspase-7 proteins as well as the inhibition of the expression or induction of the phosphorylation of the Bcl-2 protein $[26,28]$. In LNCaP cells, the $70 \%$ EEL $(228 \mu \mathrm{g} / \mathrm{mL})$ stimulates apoptotic effects by activation of the caspase-dependent pathway and dissipation of the MMP, while pretreatment with Z-VAD-FMK completely abolishes licorice-induced apoptotic cell death [23]. HEEL also excites apoptosis in DU 145 and 4 T1 cells by activating caspase- 9 , caspase- 8 , caspase- 7 , caspase- 3 , and PARP, upregulating Fas and DR4, and inducing the dissipation of the MMP and the release of cytochrome c [27,29]. In addition, the $70 \%$ MEL induces apoptosis in U-937 cells [21].

\section{Induction of autophagy}

The treatment of $228 \mu \mathrm{g} / \mathrm{mL} 70 \%$ EEL for $24 \mathrm{~h}$ in LNCaP cells induces autophagy-related cell death by the downregulation of the $\mathrm{Bcl}-2$ protein and inhibition of the mTOR pathway [23].

\section{Inhibition of angiogenesis}

The $50 \%$ ethanol (volume, $\mathrm{CH}_{3} \mathrm{CH}_{3} \mathrm{OH}: \mathrm{H}_{2} \mathrm{O}=50: 50$ ) extracts of licorice inhibits angiogenesis by reducing the VEGF level and microvessel density count in the peritoneum of Ehrlich ascites tumor cells in EAT-bearing mice [30].

\section{In vivo anticancer effects}

In 4 T1-injected female BALB/c mice, the addition of HEEL $(5 \mathrm{mg} /$ $\mathrm{kg}$ ) to drinking water inhibits the tumor volumes by reducing the expression of CDK2, CDK4, and PCNA proteins, without affecting the body weight of the mice [27]. I. p. of MEL ( $500 \mu \mathrm{g}$ ) or aqueous extracts of licorice $(600 \mu \mathrm{g})$ for $7 \mathrm{~d}$ inhibits the growth of EAT cells and the formation of ascitic fluid in EAT-bearing mice by angiogenesis inhibition [30]. In MDA-MB-231 xenograft Balb/c mice, p. o. of $70 \% \mathrm{EEL}(2 \mathrm{mg} / \mathrm{kg}$, once per day for 5 consecutive days, followed by a weekly administration for $44 \mathrm{~d}$ ) blocks tumor progression [22]. In addition, in mouse colon carcinoma cell CT26 xenograft BALB/c mice, treatment of $0.5,1$, and $2 \mathrm{mg} / \mathrm{kg}$ of the $95 \%$ ethanol (volume, $\mathrm{CH}_{3} \mathrm{CH}_{3} \mathrm{OH}: \mathrm{H}_{2} \mathrm{O}=95: 5$ ) extracts of licorice (95\% EEL) inhibits tumor volume by $38 \%, 57 \%$, and $71 \%$, respectively. The combined treatment of $2 \mathrm{mg} / \mathrm{kg} 95 \%$ EEL and cisplatin evidently decreases cisplatin-induced nephrotoxicity and hepatotoxicity by inhibiting of cisplatin-induced oxidative stress [31].

\section{Purified Compounds from Licorice \\ $\nabla$}

A panel of purified anticancer compounds has been isolated and identified from licorice ( $\bullet$ Fig. 1 ), including triterpenoids GL and GA, flavonoids ISLG, LCA, LCB, LCE, LG, IAA, GBD, ISLT, and LRD, phenolic LCM, GLY, and $\beta$-hydroxy-DHP. Among these substances, GA, ISLG, and LCA have been extensively studied and present evident anticancer effects by inhibiting cancer cell proliferation, inducing cell cycle arrest, apoptosis, and autophagy, and inhibiting metastasis and angiogenesis.

\section{Triterpenoids}

Triterpenoids are the main ingredients and characteristic compounds in licorice. More than 18 triterpenoid saponins, such as GL, GA, licorice-saponin A3, and licorice-saponin L3, have been isolated [9]. At present, GL and its aglycone GA have been widely demonstrated to present evident anticancer effects both in vitro and in vivo. In addition, GL and GA have been utilized as hepatic- targeting ligands in targeted drug delivery systems for HCC treatment because of highly expressed target binding sites in liver cells $[32,33]$.

\section{Glycyrrhizic acid}

Inhibition of proliferation: GL (100 $\mu \mathrm{M})$ exhibits no or slight cytotoxicity on several types of cancer cells, such as melanoma cells SK-MEL-2, SK-MEL-28, and B16 as well as human cervix tumor cell SiHa [34-36]. Meanwhile, the inhibitory effect of GL on cancer cells emerges at relatively higher concentrations. GL inhibits mouse leukemia cell WEHI-3 and human leukemia cell TF-1 in a dose-dependent manner [37,38]. The treatment of HepG2 with GL for $24 \mathrm{~h}$ exhibits an $\mathrm{IC}_{50}$ of more than $1.2 \mathrm{mM}$ [39]. In addition, the proliferation and growth of human lung cancer cell A549 [40], glioblastoma cell U251 [41], and human prostate cancer cells LNCaP [42] and DU 145 [42] are inhibited by GL with $\mathrm{IC}_{50} \mathrm{~s}$ at the millimole level.

Induction of cell cycle arrest: The $200 \mu \mathrm{M}$ to $400 \mu \mathrm{M}$ GL concentration range induces dose- and time-dependent G0/G1 phase arrest in WEHI-3 cells [37].

Induction of apoptosis: GL triggers apoptotic cell death in various cancer cells, such as WEHI-3 [37], LNCaP and DU 145 [42], MCF7 [43], U251 [41], and A549 [40]. This activation may be mediated by the promotion of ROS production [37], reduction of MMP [37], deactivation of the NF-kB pathway [41], and induction of DNA damage $[37,42]$.

Inhibition of metastasis: In a melanoma cell B16F10-implanted mouse model, GL inhibited pulmonary metastasis by regulating tumor-associated Thelper type 2 cells [44]. GL also inhibited human leukemia cell TF- 1 migration via inhibition of the Akt/mTOR/ STAT3 cascade [38].

Inhibition of angiogenesis: A previous study indicated that $82 \mu \mathrm{g} /$ $\mathrm{mL} \mathrm{GL}$ increases tube formation, which is critical for angiogenesis [45]. However, recent studies suggest that the "no cytotoxicity concentration" of GL $(100 \mu \mathrm{M})$ decreases the angiogenic activity of bladder cancer cell ECV304 by decreasing motility, invasion, and tube-forming properties by blocking ROS generation and extracellular ERK activation [46].

Chemosensitization or radiosensitization: GL reverses cisplatin resistance in the hepatocellular carcinoma cell Huh7 by inhibiting cisplatin efflux from the cells [47]. Pretreatment of $30 \mu \mathrm{M}$ of GL enhances UVB-induced apoptosis in SK-MEL-28 cells [35]. Furthermore, GL is identified as an inhibitor of Ku86, one of the key proteins in reducing radiotherapy efficacy by repairing DNA breaks on cancer cells [48]. In SKH-1 mice, UVB-induced cancer formation and apoptotic sunburn cells can be blocked by pretreatment with GL [49].

Others: The overexpression of the HMGB1 protein often results in cancer cell proliferation and motility as well as angiogenesis [5053]. GL can directly inhibit the DNA binding activity of HMGB1 to decrease tumor proliferation $[52,54,55]$. GL inhibits proliferation and induces apoptosis in A549 cells (TxAS protein overexpression) by inhibiting TxAS expression and activity. However, the antiproliferative effect of GL disappears with TxAS protein knockdown. Interestingly, GL cannot inhibit lung cancer cell NCI-H23 proliferation (TxAS protein low expression). When NCI-H23 cells are transfected with TxAS cDNA, GL completely suppresses the growth of NCI-H23 cells [40]. In addition, GL inhibits the activity of NAT and DNA-2-aminouorene adduct formation in colon cancer cell COLO 205 [56]. This combination of NAT and DNA-2-aminouorene is associated with the increased risk of several types of cancer [57-59]. Several hepatic TDDS utilizing GL as a hepatic lig- 


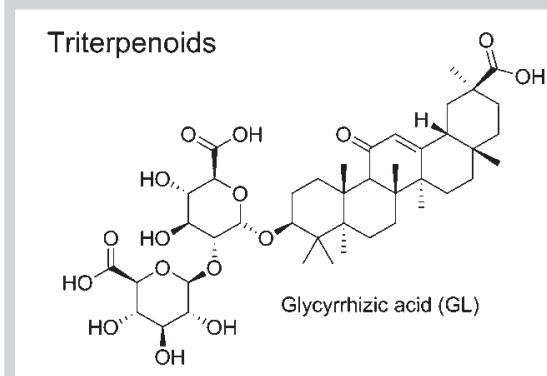

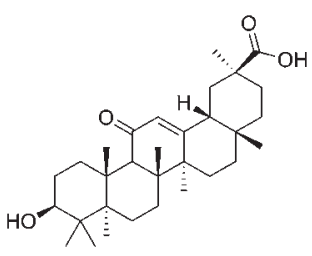

Glycyrrhetinic acid (GA)
Flavonoids<smiles>O=C(/C=C/c1ccc(O)cc1)c1ccc(O)cc1O</smiles>

Isoliquiritigenin (ISLG)<smiles>C=CC(C)(C)c1cc(/C=C/C(=O)c2ccc(O)cc2)c(O)cc1OC</smiles>

Licochalcone A (LCA)<smiles>COc1c(/C=C/C(=O)c2ccc(O)cc2)ccc(O)c1O</smiles>

Licochalcone B (LCB)
Fig. 1 Chemical structures of the anticancer compounds isolated from licorice.<smiles>C=C(C)C(O)c1cc(/C=C/C(=O)c2ccc(O)cc2)cc(OC)c1</smiles>

Licochalcone E (LCE)<smiles>O=C1CC(c2ccc(O)cc2)Oc2cc(O)ccc21</smiles><smiles>CC(C)=CCc1cc(-c2coc3cc(O)c(O)c(O)c3c2=O)cc(O)c1O</smiles><smiles>CC1(C)C=Cc2c(ccc3c2OCC(c2ccc(O)cc2O)C3)O1</smiles>

Liquiritigenin (LG)

Isoangustone A (IAA)<smiles>COc1c(CC=C(C)C)c(O)cc2c1CC(c1ccc(O)c(CC=C(C)C)c1O)CO2</smiles>
Glabridin (GBD)

$$
\text { Isoliquiritin (ISLT) }
$$

Licoricidin (LRD)

\section{Phenolics}<smiles>COc1c(CC=C(C)C)c(O)cc2oc(-c3ccc(O)cc3O)cc12</smiles><smiles>CC(C)=CCC1C(=O)c2c(oc3cc(O)ccc23)C(=O)Oc2ccc(O)cc21</smiles><smiles>O=C(CC(O)c1ccc(O)cc1)c1ccc(O)cc1O</smiles>

1-(2,4-dihydroxyphenyl)-3hydroxy-3-(4'-hydroxyphenyl) 1 -propanone ( $\beta$-hydroxy-DHP)

and have been developed, such as GL modified O-carboxymethyl chitosan nanoparticle loaded paclitaxel [60], GL modified N-caproyl chitosan nanoparticles [61], and GL modified chitosan nanoparticles [62]. These nanoparticles preferentially accumulate in HCC cells to enhance anti-HCC effects and to reduce the side effects of chemotherapeutics.

In vivo anticancer effects: Several in vivo anticancer research studies on GL have been conducted. In an ovariectomized mouse model, GL (p.o.) suppressed M-methyl-N-nitrosourea solutioninduced endometrial cancer progress by inhibiting the expression of COX-2, TNF- $\alpha$, and IL-1 [63]. In Renca cell-implanted BALB/c mice, GL (p.o., $50 \mathrm{mg} / \mathrm{kg}$, once a day for a week) suppressed about $35 \%$ of tumor weight and $60 \%$ of tumor volume by reducing angiogenesis [46]. In acetate-induced hyperproliferative activity in Wistar rats, GL (p. o., $300 \mathrm{mg} / \mathrm{kg}, 5 \mathrm{~d}$ ), before acetate i.p., significantly inhibited tumor promotion by decreasing ODC activity and DNA synthesis [64]. In A549 tumor xenograft nude mice, GL (i. p., $50 \mathrm{mg} / \mathrm{kg}$ ) also inhibited tumor growth by inhibition of TxA2 expression [40]. In addition, p. o. of GL in drinking water to SENCAR mice inhibited TPA- and DMBA-induced skin tumorigenesis by decreasing ODC activity and DNA synthesis $[65,66]$. I. m. of BALB/c mice with GL $(2 \mathrm{mg})$ also decreaseed the diethylnitrosamine-induced incidence rate of hepatocellular carcinoma from $64 \%$ to $21 \%$ [67].

\section{Glycyrrhetinic acid}

Inhibition of proliferation: GA inhibits cell proliferation in a series of cancer cells, including human cervix cancer cell SiHa [34], melanoma cells 518A2 [68], SK-MEL-2, and SK-MEL-28 [35], HCC cell HepG2 [39], human epithelial ovarian cancer cells OVCAR-3 and SK-OV-3 [69,70], gastric cancer cells BGC823 and SGC7901 [71], human breast cancer cell MCF7 [68,72], lung cancer cells NCIH460 and A549 [68, 73], human pharynx cancer cell FaDu, human submandibular cancer cell A-253, human skin cancer cell A-431, anaplastic thyroid cancer cells 8505 C and SW1736 [68], human prostate cancer cells LNCaP and DU-145 [74], colon cancer cells DLD-1, HCT 116, HCT-8, HT-29, and SW480 [68, 75], human bladder cancer cell NTUB1 [76], and human promyelocytic leukemia cell HL-60 [77]. In addition, GA exhibits the most tumor-selective toxicity among other clinical drugs (adriamycin, cisplatin, cytarabine, etoposide, fluorouracil, and manumycin A) through GSH downregulation [78-80]. The same GA concentration also inhibits the proliferation of MCF7 cells without affecting immortalized normal mammary epithelial cells [81]. 
Induction of cell cycle arrest: GA obviously induces G1 phase arrest in HepG2, A549, and NCI-H460 cells in a concentration-dependent manner $[39,82]$. In BGC823 and SGC7901 cells, GA triggers $\mathrm{G} 2$ phase arrest in concentration- and time-dependent manners by upregulation of p21 and downregulation of cdc2 and cyclin B1 expression [71].

Induction of apoptosis: GA induces apoptosis in a panel of cancer cells, including HepG2 [39, 83], SK-MEL-2 [35], DU 145 [74], SiHa [34], stomach cancer cell KATO III [71,84], HL-60 [77,84], NCIH460 and A549 [68,73], BGC823 and SGC7901 [71], and MCF7 [72,81] with the activation of caspase-8 [39], caspase-9 [39,73, 81], caspase-3 [34,73], PARP [41,73], Bax [81], and Bim [81] as well as the inhibition of the protein expression of Bcl-xL $[39,73]$, Bcl-2 [39, 73, 81], Bid [71], and connexin 32 [39]. The induction of MMP dysfunction $[34,81]$ and DNA damage [39,81], increase of the intracellular $\mathrm{Ca}^{2+}$ concentration [72] and cytochrome $\mathrm{c}$ release $[34,71,81]$, upregulation of ROS generation, depletion of glutathione [34], and reduction of Akt kinase activity [81] all participate in GA-induced apoptosis. GA also induces apoptosis by suppressing the pro-survival mediator phosphorylation of PKC $\alpha / \beta$ II and activating the JNK kinase. Pretreatment of the PKC promoter or JNK inhibitor reverses GA-induced apoptosis [73]. Furthermore, GA potentiates the Hsp90 inhibitor- and trichostatin A-induced apoptotic effect by activation of the caspase-8- and Bid-dependent pathways $[69,70]$.

Induction of autophagy: GA obviously induces autophagy in a concentration-dependent manner by activation of the ERK pathway in HepG2 and Hep3B cells, and inhibition of autophagy by chloroquine or bafilomycin A1 increases the GA-induced apoptosis, suggesting that the GA-stimulated autophagy might decrease its anticancer effects [83].

Inhibition of metastasis: GA concentration dependently inhibits the metastasis of LNCaP cells by downregulating MMP-9 and VEGF via inhibition of PI3 K/Akt-mediated NF- $k$ B activity [85]. GA also inhibits tube formation of HUVECs and invasion of DU145 cells by decreasing the expression of NF- $k B$, VEGF, and MMP9 [74]. In breast cancer cells, GA inhibits MMP-2 and MMP-9 expression via breaking p38-AP1 signaling [86].

Chemosensitization or radiosensitization: Combined treatment of $50 \mu \mathrm{M}$ GA evidently enhances the antiproliferative and proapoptotic effects of mitomycin c, doxorubicin, and camptothecin in SiHa cells [34]. The proliferative inhibition of vinblastine in P-glycoprotein-overexpressing human carcinoma KB-C2 and doxorubicin in $\mathrm{KB} / \mathrm{MDR}$ cells are also enhanced with the combined treatment of GA [87].

Others: GA induces anoikis-like cell death and disturbs cytoskeletal protein expression in central nervous system tumorigenic cells [88]. In NSCLC cells, GA inhibits cell proliferation by inhibiting the activity of the thromboxane synthase protein, which is overexpressed in NSCLC and carries a poor prognosis [89]. GA also reverses hepatic stellate cell-mediated immunosuppression by enhancing the ability of T cells to attack tumor cells in the tumor microenvironment [90]. In addition, GA inhibits the aldo-keto reductase 1B10, which has been recently identified as a tumor marker in several types of cancers [91]. Furthermore, GA has been widely utilized as a liver ligand in HCC TDDS to enhance the anticancer effects and to reduce the side effects of chemotherapeutic drug-loaded nanoparticles [92-94].

In vivo anticancer effects: In an SGC7901 xenograft nude mice model, subcutaneous injection of GA $(30 \mathrm{mg} / \mathrm{kg})$ inhibited the average weight of the subcutaneous tumor from $2.8 \mathrm{~g}$ to $0.7 \mathrm{~g}$ and induced apoptosis by decreasing the expression of Bid [71].
In DMBA- and TPA-induced skin tumors in SENCAR mice, GA pretreatment resulted in the protection against tumor initiation and promotion [95]. In hepatoma cell H22-bearing mice, an i.v. of GAmodified alginate nanoparticle-loaded doxorubicin $(7 \mathrm{mg} / \mathrm{kg}$ doxorubicin, once every $4 \mathrm{~d}$ for $16 \mathrm{~d}$ ) evidently inhibited tumor growth as evidenced by the tumor weight inhibitory rate and the mean tumor volume of about $76.6 \%$ and $2.9 \mathrm{~mm}^{3}$ in the GAmodified alginate nanoparticle loaded doxorubicin group, respectively, compared with $52.6 \%$ and $9.2 \mathrm{~mm}^{3}$ in the doxorubicin group. In addition, the side effects of doxorubicin are obviously decreased after being loaded with GA-modified alginate nanoparticles [96].

\section{Flavonoids}

The flavonoids of licorice include various types, such as flavanones or flavanones (LG, LT, and licoflavanone), chalcones (ISLG, ISLT, LCA, LCB, and LCE), isoflavans (IAA, GBD, and LRD), and isoflavones (glabrone, licoisoflavone $A$, and gancaonin $H$ ) [9]. These flavonoids present significant anticancer, antioxidative, antimicrobial, and antiviral effects among others. [6,97,98]. According to this study, chalcones, ISLG, LCA, and IAA, in particular, are licorice anticancer compounds that act mainly by the induction of cell cycle arrest, apoptosis, and autophagy as well as the inhibition of metastasis and angiogenesis.

\section{Isoliquiritigenin}

Inhibition of proliferation: ISLG inhibits cell proliferation in human cervical cancer cells C-33 A, Ca Ski, HeLa, SiHa, and U14 [99-102], gastric cancer cells AGS, MKN-28, MKN-45, and SGC7901 [103], colon cancer cells COLO 320DM, Colon 26, CT26, HCT 116, HT-29, and RCN-9 [104-106], prostate cancer cells C42, DU 145, and LNCaP [107-109], myeloma cells ARH-77, CZ-1, MPC-11, RPMI 8226, SP2/0, and U266 [110], breast cancer cells MCF7 and MDA-MB-231 [111,112], human promyelocytic leukemia cell HL-60 [113], lung cancer cells A549, HCC827, NCI-H1650, and NCI-H1975 [114-116], human epithelial ovarian cancer cell SK-OV-3 [117], human glioma cell U-87 [118]; mouse renal cancer cell Renca [119], HCC cell HepG2 [120-122], and mouse melanoma cell B16-F0 [123] in time- and dose-dependent manners. Furthermore, ISLG presents lower toxicity to normal cells (gingival fibroblast cell HGF, periodontal ligament fibroblast cell HPLF, normal myometrium cells, and normal intestinal epithelial tissue cell IEC-6) $[108,109,124,125]$ than to cancer cells (oral cancer cells HSC-2 and HSC-3, submandibular gland cancer cells HSG and HL-60, and uterine leiomyoma cells), indicating that ISLG may be a promising lead compound for cancer therapy.

Induction of cell cycle arrest: The phase of cell cycle arrest induced by ISLG varies among the cancer cells and treatment time. ISLG induces cell cycle arrest in U266 [110], C-33 A, Ca Ski, HeLa, SiHa, U14 [99, 101, 126], HCT 116 [104], A549 [114], HepG2 [122], uterine leiomyoma cells [125], and oral squamous cell carcinoma [127]. ISLG induces $G 2 / M$ phase arrest by decreasing the protein expression of CDK2, cyclin B, cyclin A, cdc2, cdc25 C, and human papillomavirus type 16 E6 $[99,101,104,125]$, activating the Rb, p53, p21, and ataxia telangiectasia mutated proteins $[99,101$, $114,115,122,125,126]$, inducing DNA damage [126], and inhibiting the activity of topoisomerase II [99]. In U-87 cells, ISLG induces both $\mathrm{S}$ and G2 phase arrest by inducing the expression of p21 and p27 [118]. In MPC-11 cells, ISLG hinders the G1 phase [110]. Interestingly, the cell phase arrest by ISLG in DU 145 is time-dependent. Within $2 \mathrm{~h}$ of treatment, ISLG induces G1 arrest by decreasing the protein expression of cyclin D1, cyclin E, and 
CDK 4 and increasing p27 expression [128], whereas ISLG induces $\mathrm{S}$ and G2/M arrest within $4 \mathrm{~h}$ to $24 \mathrm{~h}$ treatment by increasing the expression of cyclin B and phosphorylation of cdc2 [107,128]. The ISLG-induced cell cycle arrest in A549 is controversial. Ii et al. reported that ISLG induces G2/M arrest in A549 in concentration$(15,30$, and $40 \mu \mathrm{M}$ after $24 \mathrm{~h}$ treatment $)$ and time-dependent ( $40 \mu \mathrm{M}$ after $4,8,16$, and $24 \mathrm{~h}$ treatment) manners by upregulating p21 mRNA [114]. However, Hsu et al. indicated that ISLG treatment ( 20 and $40 \mu \mathrm{M}$ ) for $24 \mathrm{~h}$ induces G1 phase arrest with the increasing protein expression of $\mathrm{p} 53$ and p21 [115].

Induction of apoptosis: ISLG induces apoptosis in various cancer cells, such as HT-29, HCT 116, COLO 320DM, and Colon 26 [104, 106, 129, 130], MCF7 and MDA-MB-231 [111,131], HepG2 [120122], HeLa [99-101], Ca Ski, SiHa, C-33 A [101], U266 [110], DU 145 [109], SK-OV-3 [117], HL-60 [124], A549, HCC827, NCIH1650, and NCI-H1975 [115,116], U-87 [118], adenoid cystic cancer cells ACC-2 and ACC-M [132], gastric cancer cell MGC803 [133], and uterine leiomyoma cells [125] by activating caspase-9 $[99,101,109,111,124,130]$, caspase-8 $[101,109,122$, 124], caspase-7 [109], caspase-3 [101,104,106,109,111,124, $125,132]$, PARP $[100,101,104,109,111,125,132]$, Bax [99,101, 109,120,122,132,134], Bak [99], Fas [109,115,122,125], FasL [109], and Bid [109] as well as inhibiting Bad [111], Bcl-xL [99, 104,110,111,121,134], and Bcl-2 [99,101,104,110,120,121, 125,132] activities.

Potential mechanisms may involve downregulating the arachidonic acid metabolic network by inhibiting the mRNA expression of multiple key enzymes, such as phospholipase A2, COX-2, and cytochrome P450 4 A [111], deactivating the PI3 K/Akt and NF$\kappa B$ pathways [111,121], increasing the protein expression of p53 and p21 [101,122], increasing intracellular ROS production [100, $117,120]$, triggering ER stress by the upregulation of ER stressrelated molecules $\alpha$-subunit of eukaryotic initiation factor 2 , $78 \mathrm{kDa}$ glucose-regulated protein, X-box binding protein $1 \mathrm{ex}-$ pression, and cleavage of activating transcription factor $6 \alpha$ [117], thus enhancing the concentration of intracellular $\mathrm{Ca}^{2+}$ [133], inducing MMP dysfunction [99, 101,109, 133], and increasing the release of mitochondrial cytochrome $c[101,109,111]$. In addition, the decreased protein expression of human papillomavirus type $16 \mathrm{E} 6$ and cellular inhibitors of apoptosis protein expression [101,121] and the enhanced release of smac/diablo from the mitochondria into the cytoplasm [109] as well as inhibited glucose transmembrane transport [134] are also observed in ISLG-induced apoptosis.

Induction of autophagy: Both in vitro and in vivo studies have demonstrated that ISLG activates autophagy by suppressing the mTOR pathway in adenoid cystic carcinoma cells, and the inhibition of autophagy obviously decreases the ISLG-induced cell death [132].

Induction of differentiation: In HL-60 cells, $10 \mu \mathrm{g} / \mathrm{mL}$ ISLG changes the cell morphology from round to star shape by enhancing the protein expression of terminal differentiation markers CD11b and CD14 and increasing the nitroblue tetrazolium chloride reductive activity [113]. ISLG also induces B16-F0 cell differentiation with morphological changes, ROS generation, and melanogenesis. However, pretreatment with an ROS inducer or scavenger either increases or depletes ISLG-induced cell differentiation and melanin secretion $[86,123]$. Furthermore, NADPH oxidase-derived ROS generation presents a positive regulation in ISLG-induced HL-60 cell differentiation [135].

Inhibition of metastasis: The epidermal growth factor induced the expression of uPA, MMP-9, VEGF, ICAM, VCAM, and integrin- $\alpha 2$, which are essential for cell adhesion, migration, and invasion and are blocked by ISLG by decreasing the DNA binding activity of AP-1 and the phosphorylation of JNK [136]. ISLG also inhibits NF- $k B$ degradation and ROS generation, subsequently blocking VCAM and E-selectin expression to inhibit the adhesion of human endothelial cells $[137,138]$. In addition, in highly metastatic MDA-MB-231 cells, the nontoxic concentration of ISLG $(10 \mu \mathrm{M})$ inhibits the secretion and protein expression of VEGF, MMP-2, and MMP-9 by inhibiting hypoxia-inducible factor 1- $\alpha$ protein expression, decreasing p38 and PI3 K/Akt activity, and inhibiting the DNA binding activity of NF- $k \mathrm{~B}$ [112]. ISLG also decreases COX2 and CYP 4 A signaling to inhibit MDA-MB-231 and BT-549 metastasis by preventing anoikis resistance, migration, and invasion [131]. Furthermore, in Renca xenograft BALB/c male mice, 0.1, $0.5,2$, and $10 \mathrm{mg}$ of ISLG (i.p., once a day for $10 \mathrm{~d}$ ) decreases $40.59 \%, 45.59 \%, 60.00 \%$, and $68.23 \%$ of metastatic nodules in the lung, respectively, by decreasing the amount of VEGF and activating the immune system. These ISLG doses are approximately $1 / 6$ to $1 / 600$ of the lethal dose 50 [119].

Inhibition of angiogenesis: Previous in vitro and in vivo studies have demonstrated that the antiangiogenesis effect of the water extractions of licorice root mainly depend on ISLG, which exhibits the most antitube formation ability among other licorice-derived flavonoids $[45,139]$. In addition, the phorbol myristate acetateinduced motility, tube formation, and activation of MMP-2 can be inhibited by ISLG treatment by blocking the JNK and p38 pathways in HUVECs [140]. Furthermore, after treating MDA-MB-231 implanted Balb/c mice, ISLG (p. o., $10 \mathrm{mg} / \mathrm{kg}, 5$ times a week for 5 weeks) remarkably decreased the number of lung surface metastases by decreasing the intratumoral levels of MMP-2 and MMP-9 [131].

Chemosensitization or radiosensitization: Pretreatment of $10 \mu \mathrm{g} /$ mL ISLG for $6 \mathrm{~h}$ evidently enhances the radiosensitivity of HepG2 through the disturbance of the redox status and inhibition of nuclear factor erythroid-2-related factor 2 expression [120]. In cervical cancer cells, the combined treatment of ISLG upregulates the inhibitory effects of $\mathrm{CP}$ both in vitro and in vivo, and the $\mathrm{CP}$ induced genotoxic activity is decreased by the inhibition of DNA strand breaks in white blood cells and micronucleus formation in polychromatic erythrocytes [102]. Furthermore, in CT26 colon carcinoma cell inoculated BALB/c mice, ISLG (p. o., $1 \mathrm{mg} / \mathrm{kg}$ ) inhibits tumor growth by $52 \%$. By combining with cisplatin, the tumor growth inhibition of the combination is enhanced to $79 \%$, and cisplatin-induced nephrotoxicity and hepatotoxicity are alleviated [105].

Others: ISLG also regulates the expression and activity of certain cancer-related enzymes. The polymorphisms of the CYP19 enzyme have been implicated in the etiology of breast cancer [141, 142]. In wild-type MCF7 cells, ISLG inhibits the protein expression and transcriptional activity of CYP19 by inhibiting the MEK/ERK pathway and the activity of promoters I.3 and II [142]. ISLG decreases polycylic aromatic hydrocarbon-induced expression, which is associated with the initiation of cancer, by antagonizing aryl hydrocarbon receptor translocation [143]. ISLG also inhibits mammary carcinogenesis by decreasing breast cancer stem cells [144]. Furthermore, ISLG inhibits the ErbB3 protein, which is frequently observed in human cancer cells and currently constitutes the primary target of anticancer strategies [145].

In vivo anticancer effects: The in vivo anticancer effects of ISLG in several animal models have also been documented. In MDA-MB-231 xenograft nude mouse models, treatment of ISLG (i. p., $100 \mathrm{mg} / \mathrm{kg}$ ) for 5 weeks evidently decreases tumor weight 
by $62.3 \%$ by decreasing the intratumoral $\mathrm{PGE}_{2}, 220$-HETE, and phosphorylation of Akt levels and by inducing the expression of intratumoral cleaved caspase- 3 and cleaved PARP productions [111]. In U266 xenograft SCID mice, ISLG (i.p.) decreases tumor volume by decreasing the expression of IL- 6 and MVD as well as the phosphorylation of ERK and STAT3 [110]. In ACC-M cell-implanted BALB/c nude mice, ISLG (p. $0 ., 0.5 \mathrm{~g} / \mathrm{kg}, 30 \mathrm{~d}$ ) inhibits tumor growth by the induction of mTOR-dependent autophagic and apoptotic cell death [132]. In ddY mice, ISLG (p. o., 15 ppm in drinking water) suppresses the AOM-induced colonic aberrant crypt focus and cancer formation, with an inhibitory ratio of $37.3 \%[146]$.

\section{Licochalcone A}

Inhibition of proliferation: LCA dose- and time-dependently inhibits cell proliferation of several kinds of cancer cells, such as MKN-28, SGC7901, AGS, and MKN-45 [103], HepG2, Hep3B, and SNU878 [147], LNCaP [23,148], prostate cancer cell PC-3 [149], colon cancer cells CT26 and HCT-15 [150,151], OVCAR-3 and SK-OV-3 [151,152], HeLa [153], bladder cancer cell T24 [154, 155], A549 [151], oral squamous cancer cells HN22 and HSC4 [156], and malignant pleural mesothelioma cells MSTO-211 H and H28 [127], gastric cancer cell BGC-823 [157]. LCA presents the highest cytotoxicity against multiple gastric cancer cells and the lowest cytotoxicity to the normal human gastric epithelial cell GES-1 compared to the cell cytotoxicity of licorice compounds (ISLG, LCA, GA, GBD, GL, etc.) [103]. Furthermore, the obvious antiproliferative concentrations of LCA on cancer cells exhibit no or only slight cytotoxicity to human normal liver cells [147], human normal gastric epithelial cells [103], and human primary normal oral keratinocytes [158].

Induction of cell cycle arrest: The phase of cell cycle arrest induced by LCA varies according to the kind of cancer cells. In rat vascular smooth muscle cells, pretreatment with LCA evidently suppresses platelet-derived growth factor-induced cell proliferation by inducing G1 phase arrest through decreasing the protein expression of cyclin A, cyclin D, CDK2, and CDK4, inhibiting the phosphorylation of $\mathrm{Rb}$ and ERK, and increasing the protein expression of p27 [159]. Induction of G1 phase arrest by LCA is also observed in LNCaP cells [23]. However, in MKN-28 and PC-3 cells, LCA induces $G 2$ phase arrest by reducing the protein expression of cyclin A, cyclin B, cyclin D, cyclin E, cdc2, CDK4, and CDK6 as well as the phosphorylation of $\mathrm{Rb}[103,149]$.

Induction of apoptosis: LCA presents proapoptotic effects in bladder cancer cell T24 [155], cervical cancer cell HeLa [153], HepG2 [34,147], OVCAR-3 and SK-OV-3 [152], MKN-28, AGS, and MKN45 [103], LNCaP and PC-3 [23,148,149], KB, HSC4, and HN22 [156,158], MCF7 [160], and BGC-823 [157] as well as HL-60 [160] by activating caspase-9 [147,152,155], caspase-8 [152, 158], caspase-4 [147], caspase-3 [147,152,155,156,158], PARP $[103,147,152,155,158,160]$, Bax [103,152,155], FasL [158], and p53 [152] proteins as well as inhibiting Bcl-2 [103,152,155, 160], Bid [152], Bcl-xL [152], and survivin [152] activity. Triggering ER stress [155], elevating ROS generation [155,157], and inducing MMP dysfunction $[152,155]$ may be the potential mechanisms for LCA-induced apoptosis.

Induction of autophagy: $12.5 \mu \mathrm{M}$ of LCA induces autophagic cell death by the inhibition of Bcl-2 and mTOR in LNCaP cells, as evidenced by the conversion of the cytosolic form of microtubuleassociated protein light-chain 3 to a lipidized form as well as abundant autophagic vacuole formation [23].
Inhibition of metastasis: In oral squamous cancer cell SCC-25, $50 \mu \mathrm{g} / \mathrm{mL}$ of LCA evidently inhibits the motility, adhesion, migration, and invasion of cancer cells with decreased MMP-2 and NF$\kappa \mathrm{B}$ activities [161].

Inhibition of angiogenesis: The antiangiogenesis effects of LCA were also studied. The proliferation, migration, and tubule formation of HUVECs are inhibited by $20 \mu \mathrm{M}$ of LCA treatment with decreasing levels of IL-6 and IL-8. To further study the mechanisms, the VEGF-stimulated phosphorylation of VEGFR-2 is blocked by LCA. Upon VEGFR-2 protein knockdown, the LCAstimulated inhibitory effect on proliferation, migration, and tube formation of HUVECs is depleted [162]. LCA also inhibits plateletderived growth factor-induced rVSMC proliferation by decreasing the phosphorylation of ERK [159]. In a CT26 transplant BALB/c mice model, LCA (p. o., $30 \mathrm{mg} / \mathrm{kg}$, daily for 2 weeks) inhibits tumor growth with an average tumor size from $899 \pm 59 \mathrm{~mm}^{3}$ to $333.9 \pm 53.8 \mathrm{~mm}^{3}$ by the inhibition of tumor angiogenesis and the promotion of apoptosis [162].

Chemosensitization: Treatment with $7.5 \mu \mathrm{M}$ of LCA increases $10 \mu \mathrm{M}$ of geldanamycin-induced cell death from $36 \%$ to approximately 74\% in OVCAR-3 cells by enhanced geldanamycin-induced apoptosis-related protein activation and ROS formation, whereas the combined effect is decreased by the addition of oxidant scavengers [163]. In addition, the antiproliferative effects of paclitaxel and vinblastine can be enhanced by the combined treatment with LCA [160].

Others: LCA inhibits the proliferation of A549, SK-OV-3, SK-MEL-2, and HCT-15 by inhibiting the activation of Top I in a concentration-dependent manner [151]. LCA also inhibits cell proliferation and survival by inhibiting the phosphorylation and nuclear localization of STAT3 [164].

In vivo anticancer effects: In the $\mathrm{AOM} /$ dextran sulfate sodium-induced colon carcinogenesis in C57BL/6 mice, 5, 15, and $30 \mathrm{mg} / \mathrm{kg}$ of LCA (p.o.) present approximately $41 \%, 75 \%$, and $98 \%$ inhibitory rates in cancer growth, respectively. In addition, tumor metastasis is inhibited by decreasing MMP-9 activity [165]. DMBA-initiated and TPA-promoted mouse skin papilloma are also inhibited by LCA [166]. In addition, in CT26 cell injected Balb/c mice, LCA (p.o.) obviously reduces cisplatin-induced nephrotoxicity and hepatotoxicity by blocking cisplatin-induced oxidative stress without affecting the chemotherapeutic efficacy of cisplatin [150].

\section{Licochalcone B}

LCB inhibits the proliferation of bladder cancer cells T24, EJ, and MB49 by inducing $S$ phase cell cycle arrest and apoptosis through the reduction of cyclin A, CDK1, CDK2, cdc25 A, cdc25B, Bcl-2, and survivin expression as well as the enhancement of Bax expression. In MB49 xenograft C57BL/6 mice models, LCB has been shown to inhibit cancer cell growth without evident toxicity to mice by assessing mice weight, serum glutamate oxaloacetate aminotranferase, and glutamate pyruvate aminotransferase [167].

\section{Licochalcone $\mathrm{E}$}

LCE inhibits the proliferation of A549, SK-OV-3, SK-MEL-2, and HCT-15 by reducing Top I activity, DNA binding activity of NF$\kappa \mathrm{B}$, and Bcl-2 expression $[151,168]$. LCE dose-dependently inhibits the migration and invasion of MDA-MB-231 and 4 T1 cells by decreasing the secretion of UPA, VEGF, and MMP-9. Furthermore, in $4 \mathrm{~T} 1$ xenograft BALB/c mice models, LCE (p.o., $14 \mathrm{mg} / \mathrm{kg}$ ) suppresses tumor growth and metastasis by reducing the expression 
of Ki67, CDK4, CDK2, cyclin A, cyclin D, VEGF, lymphatic vessel endothelial receptor-1, COX-2, and hypoxia inducible factor- 1 as the protein expressions of Bax and cleaved caspase- 3 are increased [169].

\section{Liquiritigenin}

The antiproliferative effects of LG in hepatic cancer cell SMMC7721 and HeLa cells are mainly achieved by the induction of apoptosis with the upregulation of Bax and caspase- 3 proteins as well as through the inhibition of the expression of Bcl-2 and survivin by increasing the generation of ROS, activating p53, inducing MMP dysfunction, and decreasing GSH and the activities of superoxide dismutase. Meanwhile, in pretreatment with an ROS scavenger, LG-induced apoptosis is obviously decreased [170, 171]. The noncytotoxic concentration of LG inhibits the adhesion and migration of A549 cells by decreasing MMP-2 activity, hindering phosphorylation of Akt, and activating ERK [172]. Moreover, LG inhibits the expression of VEGF in HeLa cells in a dosedependent manner. In HeLa-implanted nude mice, i.g. of LG ( $40 \mathrm{mg} / \mathrm{kg}$, once a day for $28 \mathrm{~d}$ ) also exhibits a more than $50 \%$ inhibitory rate on tumor growth by decreasing VEGF and MVD expression [173]. Furthermore, in the $\mathrm{H} 22$ bearing mice model, treatment of LG (i.g., $20 \mathrm{mg} / \mathrm{kg}$ ) inhibits the tumor growth by decreasing MDA content and inducing apoptosis [174].

\section{Isoangustone A}

The antiproliferation of IAA in SW480 [175], pancreatic cancer cells PC3, LNCaP, and DU 145 [29, 176], 4 T1 [29], and melanoma cells SK-MEL-2, SK-MEL-5, SK-MEL-28, and WM-266-4 [177] are achieved by the induction of cell cycle arrest and apoptosis. IAA induces PC3, LNCaP, SK-MEL-28, DU 145, and 4 T1 cells in G1 phase cell cycle arrest through the reduction of the protein expression of cyclin A, cyclin D, cyclin E, CDK2, and CDK4. This inhibitory effect may be achieved by the downregulation of MTOR, PI3 K, Akt, and JNK activities [27, 176,177]. IAA also induces apoptosis in SW480 and DU 145 cells by activating caspase-3, caspase-9, PARP, and DR4, suppressing Bcl-2 protein expression, disrupting MMP and ATP synthesis, and inducing cytochrome c release $[27,29,175]$. In addition, the pretreatment of Z-VAD-FMK or knockdown of the DR4 obviously attenuates IAA-induced apoptosis $[29,175]$. Furthermore, in PC3 xenograft BALB/c nude mice, IAA (i. p., $5 \mathrm{mg} / \mathrm{kg}$ ) reduces about $70.0 \%$ and $53.6 \%$ of tumor volume and tumor weight, respectively, through the inhibition of PCNA expression and the induction of G1 phase arrest [176]. In an SK-MEL-28-injected male BALB/c mice model, 2 or $10 \mathrm{mg} / \mathrm{kg}$ IAA (i.p., daily for 5 weeks) inhibits tumor volume and weight without affecting the body weight [177].

\section{Glabridin}

The migration, invasion, and epithelial-mesenchymal transition of A549, MDA-MB-231, and HUVECs can be inhibited by GBD treatment by decreasing the FAK, Src, Akt, myosin, and myosin light chain phosphorylation, the FAK and Src interaction, and the RhoA activity $[178,179]$. GBD also inhibits the migration and invasion of Huh7 and Sk-Hep-1 cells by decreasing the expression, activities, and protein levels of MMP9, phosphorylation of ERK1/ 2 and JNK1/2, upregulation of the tissue inhibitor of metalloproteinase- 1 , and downregulation of the NF- $k$ B and AP- 1 signaling pathways [180]. GBD inhibits angiogenesis in nude mice models [179]. The accumulation of daunorubicin in KB-C2 cells can be enhanced by GBD treatment [87]. Furthermore, the nontoxic concentration of GBD $(15 \mu \mathrm{M})$ prevents UVB-irradiated normal human keratinocyte damage by inhibiting ROS production and cleaved PARP expression [181]. In SK-Hep-1 xenograft BALB/C nude mice, GBD (i.p., $10 \mathrm{mg} / \mathrm{kg}$, three times a week) dramatically suppressed tumor growth without statistically significant changes in body weight [180].

\section{Isoliquiritin}

ISLT exhibits a 50-fold greater inhibitory effect on the angiogenesis of granuloma tissue than that of licorice extractions. This inhibitory effect is achieved by inhibiting tube formation [45].

\section{Licoricidin}

The noncytotoxic concentration of LRD inhibits the migration and adhesion of DU 145 cells in a concentration-dependent manner through the reduction of MMP-9, UPA, VEGF, integrin- $\alpha 2$, ICAM, and VCAM secretion [182].

\section{Phenolics}

Several licorice phenolics, such as LCM, GLY, and $\beta$-hydroxy-DHP, also demonstrated anticancer effects by the induction of cell cycle arrest and apoptosis.

\section{Licocoumarone}

LCM inhibits the proliferation of U-937 cells in a concentrationdependent manner through the induction of apoptosis [21].

\section{Glycyrol}

In human Jurkat cells, GLY induces S phase cell cycle arrest and apoptosis in time- and dose-dependent manners through the activation of Fas, caspase-8, and caspase-9 proteins [16]. It also induced cell cycle arrest, apoptosis, and defective autophagy in AGS and HCT 116 cells with the activation of the JNK pathway [38]. 1-(2,4-Dihydroxyphenyl)-3-hydroxy-3-(4'-hydroxyphenyl) 1-propanone: $\beta$-Hydroxy-DHP decreases the viability of MCF7 cells in a dose-dependent manner, and this proliferative inhibition is mainly due to induced apoptosis. The $50 \mu \mathrm{M}$ concentration of $\beta$ hydroxy DHP also induces apoptosis in HL-60 cells and G2/M cell cycle arrest in T47D cells [28].

\section{Discussion and Conclusion}

We have summarized the in vitro and in vivo anticancer properties (Tables 1 and $\mathbf{2}$ ) and potential mechanisms of mixed extracts and purified compounds from licorice ( Fig. 2). A series of licorice compounds have been indicated as possessing anticancer effects by inhibiting cancer cell proliferation and metastasis. Present studies focusing on extracts are rather limited, and the active compounds of extracts are not clear. The anticancer effects of purified compounds, such as GA, ISLG, and LCA, attracted considerably more studies than these extracts. However, most studies focus on the phenomena without detailed mechanism analysis, and in vivo anticancer effects are also restrained. In addition, the pharmacokinetic assay and maximum tolerated dose are also important for the development of licorice. Several pharmacokinetic studies of licorice compounds, such as GL, GA, ISLG, and LG, etc., have been carried out in some animal models [183185]. In an Sprague-Dawley rat model $(468 \mathrm{mg} / \mathrm{kg}$ of licorice, p.o.), the peak plasma concentrations of LG and ISLG were $2.83 \mu \mathrm{g} / \mathrm{mL}$ and $0.28 \mu \mathrm{g} / \mathrm{mL}$, respectively [186]. However, in a Sprague-Dawley rat model, the peak plasma concentrations of LG (1920 mg/kg, p.o.), ISLG (180 mg/kg, p.o.), GL (170 mg/kg, 
Table 1 The antiproliferative properties of licorice compounds in vitro.

\begin{tabular}{|c|c|c|c|c|c|c|}
\hline Compounds & Cancer tissue/disease & Cancer cell & Concentration & Inhibition rate & Method & Ref. \\
\hline \multirow{8}{*}{$\begin{array}{l}\text { Ethanol extract of roasted } \\
\text { licorice }\end{array}$} & \multirow[t]{2}{*}{ Prostate } & DU 145 & $6 \mu \mathrm{g} / \mathrm{mL}$ & $50 \%(72 h)$ & MTT & {$[24]$} \\
\hline & & MLL & $4.3 \mu \mathrm{g} / \mathrm{mL}$ & $50 \%(72 h)$ & MTT & {$[24]$} \\
\hline & Colon & HT-29 & $12 \mu \mathrm{g} / \mathrm{mL}$ & $50 \%(72 h)$ & MTT & [24] \\
\hline & \multirow[t]{2}{*}{ Breast } & MCF-7 & $30 \mu \mathrm{g} / \mathrm{mL}$ & $88 \%(48 h)$ & MTT & {$[24]$} \\
\hline & & MDA-MB-231 & $30 \mu \mathrm{g} / \mathrm{mL}$ & $82 \%(48 \mathrm{~h})$ & MTT & [24] \\
\hline & Melanoma & B16-F10 & $30 \mu \mathrm{g} / \mathrm{mL}$ & $80 \%(48 h)$ & MTT & [24] \\
\hline & \multirow{2}{*}{ Skin } & A375 & $30 \mu \mathrm{g} / \mathrm{mL}$ & $94 \%(48 h)$ & MTT & [24] \\
\hline & & A2058 & $30 \mu \mathrm{g} / \mathrm{mL}$ & $93 \%(48 h)$ & MTT & [24] \\
\hline \multirow{3}{*}{$\begin{array}{l}\text { Ethanol extract of un- } \\
\text { roasted licorice }\end{array}$} & \multirow[t]{2}{*}{ Prostate } & DU 145 & $12.3 \mu \mathrm{g} / \mathrm{mL}$ & $50 \%(72 h)$ & MTT & [24] \\
\hline & & MLL & $12.2 \mu \mathrm{g} / \mathrm{mL}$ & $50 \%(72 h)$ & MTT & [24] \\
\hline & Colon & HT-29 & $31 \mu \mathrm{g} / \mathrm{mL}$ & $50 \%(72 h)$ & MTT & [24] \\
\hline Ethanol extracts of licorice & Breast & MCF7 & $100 \mu \mathrm{g} / \mathrm{mL}$ & about $25 \%(72 \mathrm{~h})$ & MTT & [26] \\
\hline $\begin{array}{l}80 \% \text { ethanol (volume, } \\
\mathrm{CH}_{3} \mathrm{CH}_{3} \mathrm{OH}: \mathrm{H}_{2} \mathrm{O}=70: 30 \text { ) } \\
\text { extracts of licorice }\end{array}$ & Breast & MCF7 & $100 \mu \mathrm{g} / \mathrm{mL}$ & about $50 \%(72 \mathrm{~h})$ & MTT & {$[26]$} \\
\hline \multirow{2}{*}{$\begin{array}{l}70 \% \text { methanol (volume, } \\
\mathrm{CH}_{3} \mathrm{OH}: \mathrm{H}_{2} \mathrm{O}=70: 30 \text { ) } \\
\text { extracts of licorice }\end{array}$} & Leukemia & U973 & $50 \mu \mathrm{g} / \mathrm{mL}$ & about $70 \%(16 h)$ & ABS & {$[21]$} \\
\hline & Liver & HepG2 & $530 \mu \mathrm{g} / \mathrm{mL}$ & $50 \%(72 \mathrm{~h})$ & MTT & {$[20]$} \\
\hline \multirow[t]{4}{*}{ Glycyrrhizic acid } & \multirow[t]{2}{*}{ Prostate } & LNCaP & $8.5 \mathrm{mM}$ & $50 \%(48 h)$ & CCK-8 & {$[42]$} \\
\hline & & DU 145 & $12.5 \mathrm{mM}$ & $50 \%(48 h)$ & CCK-8 & {$[42]$} \\
\hline & Lung & A549 & $1 \mathrm{mM}$ & $50 \%(72 h)$ & MTS & {$[40]$} \\
\hline & Glioblastoma & U251 & $2 \mathrm{mM}$ & $28 \%(24 h), 75 \%(48 h)$, and $90 \%$ (72h) & CCK-8 & [41] \\
\hline \multirow[t]{31}{*}{ Glycyrrhetinic acid } & \multirow[t]{6}{*}{ Stomach } & AGS & $125.2 \mu \mathrm{M}$ & $50 \%(48 h)$ & MTT & [103] \\
\hline & & BGC823 & $30 \mu \mathrm{M}$ & $65 \%(24 h)$ & MTT & [71] \\
\hline & & MKN-28 & $146.7 \mu \mathrm{M}$ & $50 \%(48 h)$ & MTT & [103] \\
\hline & & MKN-45 & $157 \mu \mathrm{M}$ & $50 \%(48 h)$ & MTT & [103] \\
\hline & & SGC7901 & $30 \mu \mathrm{M}$ & $46 \%(24 h)$ & MTT & [71] \\
\hline & & SGC7901 & $135.7 \mu \mathrm{M}$ & $50 \%(48 h)$ & MTT & [103] \\
\hline & \multirow[t]{5}{*}{ Colon } & DLD-1 & $81.21 \mu \mathrm{M}$ & $50 \%(96 h)$ & SRB & [68] \\
\hline & & HCT 116 & $78.33 \mu \mathrm{M}$ & $50 \%(96 h)$ & SRB & {$[68]$} \\
\hline & & HCT-8 & $78.85 \mu \mathrm{M}$ & $50 \%(96 h)$ & SRB & [68] \\
\hline & & HT-29 & $80.09 \mu \mathrm{M}$ & $50 \%(96 h)$ & SRB & [68] \\
\hline & & SW480 & $86.80 \mu \mathrm{M}$ & $50 \%$ (96h) & SRB & [75] \\
\hline & \multirow[t]{3}{*}{ Lung } & A549 & $82.76 \mu \mathrm{M}$ & $50 \%(96 h)$ & SRB & [68] \\
\hline & & A549 & $165.7 \mu \mathrm{M}$ & $50 \%(24 h)$ & XTT & [73] \\
\hline & & NCI-H460 & $131.7 \mu \mathrm{M}$ & $50 \%(24 h)$ & XTT & [73] \\
\hline & \multirow[t]{2}{*}{ Prostrate } & $\mathrm{LNCaP}$ & $200 \mu \mathrm{M}$ & $35 \%(48 h)$ & MTT & [74] \\
\hline & & DU 145 & $200 \mu \mathrm{M}$ & $52 \%$ (48 h) & MTT & [74] \\
\hline & \multirow[t]{2}{*}{ Ovary } & OVCAR-3 & $25 \mu \mathrm{M}$ & $24 \%(24 h), 42 \%(48 h)$, and $52 \%$ ( $72 \mathrm{~h}$ ) & MTT & [69] \\
\hline & & SK-OV-3 & $25 \mu \mathrm{M}$ & $23 \%(24 h), 42 \%$ ( 48 h), and $51 \%$ ( 72 h) & MTT & [69] \\
\hline & \multirow[t]{3}{*}{ Melanoma } & SK-MEL-28 & $30 \mu \mathrm{M}$ & $55 \%(48 h)$ & MTT & [35] \\
\hline & & SK-MEL-2 & $30 \mu \mathrm{M}$ & $50 \%(48 h)$ & MTT & [35] \\
\hline & & $518 \mathrm{~A} 2$ & $83.92 \mu \mathrm{M}$ & $50 \%(96 h)$ & SRB & {$[68]$} \\
\hline & \multirow{2}{*}{ Thyroid } & $8505 C$ & $86.50 \mu \mathrm{M}$ & $50 \%(96 h)$ & SRB & [75] \\
\hline & & SW1736 & $76.93 \mu \mathrm{M}$ & $50 \%(96 h)$ & SRB & [68] \\
\hline & Cervix & $\mathrm{SiHa}$ & $50 \mu \mathrm{M}$ & $58 \%(24 h)$ & MTT & [34] \\
\hline & \multirow[t]{2}{*}{ Liver } & HepG2 & $80 \mu \mathrm{M}$ & $50 \%(72 h)$ & TBD & [39] \\
\hline & & HepG2 & $40 \mu \mathrm{M}$ & $50 \%(48 \mathrm{~h})$ & MTT & [34] \\
\hline & $\begin{array}{l}\text { Submaxillary salivary } \\
\text { gland }\end{array}$ & A-253 & $80.78 \mu \mathrm{M}$ & $50 \%(96 h)$ & SRB & {$[68]$} \\
\hline & Skin & A-431 & $79.58 \mu \mathrm{M}$ & $50 \%(96 h)$ & SRB & [68] \\
\hline & Pharynx & FaDu & $84.55 \mu \mathrm{M}$ & $50 \%$ (96h) & SRB & [75] \\
\hline & Breast & MCF7 & $84.70 \mu \mathrm{M}$ & $50 \%(96 h)$ & SRB & [68] \\
\hline & Leukemia & HL-60 & $63.2 \mu \mathrm{M}$ & $50 \%(96 h)$ & SRB & $\begin{array}{l}{[77]} \\
\text { cont. }\end{array}$ \\
\hline
\end{tabular}

p.o.), and GA (580 mg/kg, p.o.) were $37 \mu \mathrm{g} / \mathrm{mL}, 42 \mu \mathrm{g} / \mathrm{mL}, 55 \mu \mathrm{g} /$ $\mathrm{mL}$, and $90 \mu \mathrm{g} / \mathrm{mL}$, respectively [183]. More pharmacokinetic studies on licorice using different models should be carried out, and the maximum tolerated dose of licorice or pure compounds is also critical for licorice's clinical use. Also, whether the concentration of the compounds in a tumor microenvironment can reach the doses used in vitro (due to the in vitro concentrations of some compounds used being too high, such as GL) needs to be considered further. Therefore, the evaluation of the in vivo anticancer effects of licorice might be much more significant.

Although numerous proteins or genes can be affected by licorice compounds, the actual targets and mechanisms still remain un- 
Table 1 Continued

\begin{tabular}{|c|c|c|c|c|c|c|}
\hline Compounds & Cancer tissue/disease & Cancer cell & Concentration & Inhibition rate & Method & Ref. \\
\hline \multirow{45}{*}{ Isoliquiritigenin } & \multirow[t]{6}{*}{ Cervix } & $\mathrm{C}-33 \mathrm{~A}$ & $40 \mu \mathrm{M}$ & $62 \%$ ( $24 h), 64 \%$ ( 48 h), and $72 \%$ ( 72 h) & MTT & [101] \\
\hline & & Ca Ski & $40 \mu \mathrm{M}$ & $23 \%(24 h), 56 \%$ ( 48 h), and $56 \%$ ( 72 h) & MTT & [101] \\
\hline & & HeLa & $9.8 \mu \mathrm{M}$ & $50 \%(48 h)$ & $\mathrm{XTT}$ & [99] \\
\hline & & HeLa & $40 \mu \mathrm{M}$ & $42 \%$ ( $24 h), 36 \%(48 h)$, and $55 \%$ (72 h) & MTT & [101] \\
\hline & & $\mathrm{SiHa}$ & $40 \mu \mathrm{M}$ & $32 \%(24 h), 38 \%(48 h)$, and $61 \%$ (72 h) & MTT & [101] \\
\hline & & U14 & $97.56 \mu \mathrm{M}$ & about $61.57 \%(48 \mathrm{~h})$ & MTT & [102] \\
\hline & \multirow[t]{5}{*}{ Breast } & MCF7 & $10 \mu \mathrm{M}$ & $50 \%(48 h)$ & MTS & [111] \\
\hline & & MCF7 & $50 \mu \mathrm{M}$ & about $50 \%(72 \mathrm{~h})$ & MTT & [112] \\
\hline & & MCF7aro & $5 \mu \mathrm{M}$ & about $65 \%(48 \mathrm{~h})$ & MTT & [142] \\
\hline & & MDA-MB-231 & $5 \mu \mathrm{M}$ & $50 \%(48 h)$ & MTS & [111] \\
\hline & & MDA-MB-231 & $25 \mu \mathrm{M}$ & about $50 \%(72 \mathrm{~h})$ & MTT & [112] \\
\hline & \multirow[t]{6}{*}{ Colon } & СТ26 & $60 \mu \mathrm{M}$ & about $40 \%(24 h)$ and $70 \%(72 h)$ & MTT & [105] \\
\hline & & Colon 26 & $14.6 \mu \mathrm{M}$ & $50 \%(48 \mathrm{~h})$ & MTT & [106] \\
\hline & & COLO 320DM & $17.9 \mu \mathrm{M}$ & $50 \%(72 h)$ & MTT & [106] \\
\hline & & HCT 116 & $40 \mu \mathrm{M}$ & $25 \%$ (48 h), $40 \%$ ( 72 h), and 50\% (96h) & MTT & [104] \\
\hline & & HT-29 & $40 \mu \mathrm{M}$ & $30 \%(24 h), 38 \%$ ( $48 h$ ), and $42 \%$ ( $72 h$ ) & MTT & [104] \\
\hline & & RCN-9 & $19.5 \mu \mathrm{M}$ & $50 \%(48 h)$ & MTT & [106] \\
\hline & \multirow[t]{6}{*}{ Prostate } & $\mathrm{C} 4-2$ & $87 \mu \mathrm{M}$ & $50 \%(24 h)$ & MTT & [108] \\
\hline & & DU 145 & $11 \mu \mathrm{M}$ & $50 \%(48 h)$ & TBD & [107] \\
\hline & & DU 145 & $20 \mu \mathrm{M}$ & $25 \%(24 h), 39 \%(48 h)$, and $56 \%$ (72 h) & MTT & [109] \\
\hline & & LNCaP & $13 \mu \mathrm{M}$ & $50 \%(48 \mathrm{~h})$ & TBD & [107] \\
\hline & & LNCaP & $100 \mu \mathrm{M}$ & $62 \%(24 h)$ & MTT & [108] \\
\hline & & MLL & $5 \mu \mathrm{M}$ & $11 \%(24 \mathrm{~h}), 41 \%(48 \mathrm{~h})$, and $50 \%$ ( $72 \mathrm{~h}$ ) & MTT & [109] \\
\hline & \multirow[t]{6}{*}{ Myeloma } & ARH-77 & $14.6 \mu \mathrm{M}$ & about $50 \%(48 \mathrm{~h})$ & CCK-8 & [110] \\
\hline & & $C Z-1$ & $13.9 \mu \mathrm{M}$ & about $50 \%(48 \mathrm{~h})$ & CCK-8 & [110] \\
\hline & & MPC-11 & $4.4 \mu \mathrm{M}$ & about $50 \%(48 \mathrm{~h})$ & CCK-8 & [110] \\
\hline & & RPMI 8226 & $9.1 \mu \mathrm{M}$ & about $50 \%(48 \mathrm{~h})$ & CCK-8 & [110] \\
\hline & & $\mathrm{SP} 2 / 0$ & $22.9 \mu \mathrm{M}$ & about $50 \%(48 \mathrm{~h})$ & CCK-8 & [110] \\
\hline & & U266 & $8.6 \mu \mathrm{M}$ & about $50 \%(48 \mathrm{~h})$ & CCK-8 & [110] \\
\hline & \multirow[t]{4}{*}{ Stomach } & AGS & $147.3 \mu \mathrm{M}$ & $50 \%(48 h)$ & MTT & [103] \\
\hline & & MKN-28 & $167.8 \mu \mathrm{M}$ & $50 \%(48 h)$ & MTT & [103] \\
\hline & & MKN-45 & $128.4 \mu \mathrm{M}$ & $50 \%(48 h)$ & MTT & [103] \\
\hline & & SGC7901 & $157.9 \mu \mathrm{M}$ & $50 \%(48 h)$ & MTT & [103] \\
\hline & \multirow[t]{2}{*}{ Oral cavity } & HSC-2 & $79 \mu \mathrm{M}$ & $50 \%(24 h)$ & MTT & [124] \\
\hline & & $\mathrm{HSC}-3$ & $97 \mu \mathrm{M}$ & $50 \%(24 h)$ & MTT & [124] \\
\hline & \multirow[t]{2}{*}{ Liver } & HepG2 & $156.1 \mu \mathrm{M}$ & about $50 \%(48 \mathrm{~h})$ & MTT & [120] \\
\hline & & HepG2 & $41 \mu \mathrm{M}$ & about $50 \%(48 \mathrm{~h})$ & $\mathrm{XTT}$ & [121] \\
\hline & \multirow[t]{2}{*}{ Lung } & A549 & $18.5 \mu \mathrm{M}$ & $50 \%(72 h)$ & TBD & [114] \\
\hline & & A549 & $27.14 \mu \mathrm{M}$ & $50 \%(24 h)$ & $\mathrm{XTT}$ & [115] \\
\hline & \multirow[t]{2}{*}{ Leukemia } & HL-60 & $58.5 \mu \mathrm{M}$ & about $86.7 \%$ (72 h) & MTT & [113] \\
\hline & & $\mathrm{HL}-60$ & $22 \mu \mathrm{M}$ & $50 \%(24 h)$ & MTT & [124] \\
\hline & Kindey & Renca & $39 \mu \mathrm{M}$ & about $30 \%(72 \mathrm{~h})$ & ABS & [119] \\
\hline & Submandibular gland & HSG & $125 \mu \mathrm{M}$ & $50 \%(24 h)$ & MTT & [124] \\
\hline & Brain & U-87 & $40 \mu \mathrm{M}$ & $20 \%(24 h), 53 \%$ ( 48 h), and $75 \%$ ( 72 h) & MTT & [118] \\
\hline & Ovary & SK-OV-3 & $156.1 \mu \mathrm{M}$ & about $83.1 \%(24 \mathrm{~h})$ & MTT & [117] \\
\hline \multirow[t]{18}{*}{ Licochalcone A } & \multirow[t]{4}{*}{ Stomach } & AGS & $41.1 \mu \mathrm{M}$ & $50 \%(48 h)$ & MTT & [103] \\
\hline & & MKN-28 & $42 \mu \mathrm{M}$ & $50 \%(48 h)$ & MTT & [103] \\
\hline & & MKN-45 & $40.7 \mu \mathrm{M}$ & $50 \%(48 h)$ & MTT & [103] \\
\hline & & SGC7901 & $40.8 \mu \mathrm{M}$ & $50 \%(48 h)$ & MTT & [103] \\
\hline & \multirow[t]{3}{*}{ Liver } & HepG2 & $10 \mu \mathrm{M}$ & $54 \%(24 h)$ & MTT & [147] \\
\hline & & Нер3В & $10 \mu \mathrm{M}$ & $40 \%(24 h)$ & MTT & [147] \\
\hline & & SNU878 & $10 \mu \mathrm{M}$ & $38 \%(24 h)$ & MTT & [147] \\
\hline & Ovary & OVCAR-3 & $15 \mu \mathrm{M}$ & $68 \%(24 h)$ & MTT & [152] \\
\hline & & SK-OV-3 & $15 \mu \mathrm{M}$ & $61 \%(24 h)$ & MTT & [152] \\
\hline & & SK-OV-3 & $13.5 \mu \mathrm{M}$ & about $50 \%(48 \mathrm{~h})$ & SRB & [151] \\
\hline & Prostate & PC-3 & $25 \mu \mathrm{M}$ & $80 \%(48 h)$ and $83 \%(72 h)$ & TBD & [149] \\
\hline & & LNCaP & $50 \mu \mathrm{M}$ & $5.5 \%(48 h)$ & MTT & [148] \\
\hline & Colon & $\mathrm{CT} 26$ & $20 \mu \mathrm{M}$ & $56.3 \%(24 h)$ and $74.3 \%(72 h)$ & MTT & [150] \\
\hline & & HCT-15 & $10.1 \mu \mathrm{M}$ & about $50 \%(48 \mathrm{~h})$ & SRB & [151] \\
\hline & Cervix & HeLa & $50 \mu \mathrm{M}$ & $17.4 \%(24 h)$ & MTT & [153] \\
\hline & Bladder & $\mathrm{T} 24$ & $100 \mu \mathrm{M}$ & $54 \%(12 \mathrm{~h}), 64 \%$ ( $24 \mathrm{~h})$, and $79 \%$ (48 h) & MTT & [167] \\
\hline & Lung & A549 & $14.3 \mu \mathrm{M}$ & about $50 \%(48 \mathrm{~h})$ & SRB & [151] \\
\hline & Skin & SK-MEL-2 & $7.9 \mu \mathrm{M}$ & about $50 \%(48 \mathrm{~h})$ & SRB & [151] \\
\hline
\end{tabular}


Table 1 Continued

\begin{tabular}{|c|c|c|c|c|c|c|}
\hline Compounds & Cancer tissue/disease & Cancer cell & Concentration & Inhibition rate & Method & Ref. \\
\hline \multirow[t]{2}{*}{ Licochalcone B } & \multirow[t]{2}{*}{ Bladder } & T24 & $60 \mu \mathrm{M}$ & $25 \%$ ( 24 h), $55 \%$ (48 h), and $67 \%$ ( 72 h) & MTT & {$[167]$} \\
\hline & & E] & $60 \mu \mathrm{M}$ & $50 \%$ ( $24 h), 65 \%$ (48h), and $75 \%$ ( $72 h$ ) & MTT & [167] \\
\hline \multirow{4}{*}{ Licochalcone E } & Colon & HCT-15 & $10.1 \mu \mathrm{M}$ & about 50\% (48 h) & SRB & [151] \\
\hline & Skin & SK-MEL-2 & $8.5 \mu \mathrm{M}$ & about $50 \%(48 \mathrm{~h})$ & SRB & [151] \\
\hline & Lung & A549 & $17.3 \mu \mathrm{M}$ & about $50 \%(48 \mathrm{~h})$ & SRB & [151] \\
\hline & Ovary & SK-OV-3 & $15.5 \mu \mathrm{M}$ & about $50 \%(48 \mathrm{~h})$ & SRB & {$[151]$} \\
\hline \multirow[t]{6}{*}{ Liquiritigenin } & \multirow[t]{4}{*}{ Stomach } & AGS & $339.3 \mu \mathrm{M}$ & $50 \%(48 h)$ & MTT & {$[103]$} \\
\hline & & MKN-28 & $314.7 \mu \mathrm{M}$ & $50 \%(48 h)$ & MTT & [103] \\
\hline & & MKN-45 & $376.7 \mu \mathrm{M}$ & $50 \%(48 h)$ & MTT & [103] \\
\hline & & SGC7901 & $358 \mu \mathrm{M}$ & $50 \%(48 h)$ & MTT & [103] \\
\hline & Cervix & HeLa & $200 \mu \mathrm{M}$ & $24 \%$ ( 24 h), $48 \%$ ( 48 h), and $65 \%$ ( 72 h) & MTT & [171] \\
\hline & Liver & SMMC-7721 & $400 \mu \mathrm{M}$ & $76 \%(48 h)$ & MTT & {$[170]$} \\
\hline \multirow[t]{2}{*}{ Isoangustone A } & Prostrate & PC3 & $10 \mu \mathrm{M}$ & $52 \%(24 h)$ & MTT & [176] \\
\hline & Colon & SW480 & $6 \mu \mathrm{M}$ & $40 \%(24 h)$ & MTT & [175] \\
\hline \multirow[t]{4}{*}{ Glabridin } & \multirow[t]{4}{*}{ Stomach } & AGS & $69.6 \mu \mathrm{M}$ & $50 \%(48 h)$ & MTT & [103] \\
\hline & & MKN-28 & $61 \mu \mathrm{M}$ & $50 \%(48 h)$ & MTT & [103] \\
\hline & & MKN-45 & $83.7 \mu \mathrm{M}$ & $50 \%(48 h)$ & MTT & [103] \\
\hline & & SGC7901 & $84.2 \mu \mathrm{M}$ & $50 \%(48 h)$ & MTT & [103] \\
\hline Licocoumarone & Lymphocyte & U-937 & $147 \mu \mathrm{M}$ & about 75\% (16h) & ABS & [21] \\
\hline$\beta$-Hydroxy-DHP & Breast & MCF7 & $13 \mu \mathrm{M}$ & $50 \%(72 h)$ & MTT & [28] \\
\hline
\end{tabular}

ABS: Alamar Blue assay; MTT: 3-(4,5-Dimethylthiazol-2-yl)-2,5-diphenyltetrazolium bromide assay; MTS: 3-(4,5-dimethylthiazol-2-y1)-5-(3-caxboxymethoxyphenyl)-2-(4-sulfophenyl)-2 $\mathrm{H}$-tetrazolium, inner salt assay; MCF7aro: stably transfected with human CYP19 cells; XTT: 2,3-bis(2-methoxy-4-nitro-5-sulfophenyl)-5[(phenylamino)carbonyl]-2 H-tetrazolium hydroxide assay; TBD: trypan blue dye assay; SRB: Sulforhodamine B assay

Table 2 The anticancer properties of licorice compounds in vivo.

\begin{tabular}{|c|c|c|c|c|}
\hline Compounds & Models & Treatments & Outcomes & Ref. \\
\hline $\begin{array}{l}\text { Methanol extracts of } \\
\text { licorice }\end{array}$ & EAT-bearing mice & i. p., $500 \mu \mathrm{g}, 7$ days & $\begin{array}{l}\text { inhibition of growth of EAT cells and formation of } \\
\text { ascites fluid by inhibition of angiogenesis }\end{array}$ & {$[30]$} \\
\hline $\begin{array}{l}\text { Aqueous extracts of } \\
\text { licorice }\end{array}$ & EAT-bearing mice & i. p., $600 \mu \mathrm{g}, 7$ days & $\begin{array}{l}\text { inhibition of growth of EAT cells and formation of } \\
\text { ascites fluid by inhibition of angiogenesis }\end{array}$ & {$[30]$} \\
\hline $\begin{array}{l}\text { Hexane/ethanol } \\
\text { extracts of licorice }\end{array}$ & $\begin{array}{l}4 \mathrm{~T} 1 \text {-injected female BALB/c } \\
\text { mice }\end{array}$ & In drinking water, 5 mg/kg/day, & $\begin{array}{l}\text { inhibiting the tumor volumes by reducing the } \\
\text { expression of CDK2, CDK4, and PCNA }\end{array}$ & [27] \\
\hline $\begin{array}{l}70 \% \text { ethanol (vol- } \\
\text { ume, } \mathrm{CH}_{3} \mathrm{CH}_{3} \mathrm{OH} \text { : } \\
\mathrm{H}_{2} \mathrm{O}=70: 30 \text { ) ex- } \\
\text { tracts of licorice }\end{array}$ & $\begin{array}{l}\text { MDA-MB- } 231 \text { xenografted } \\
\text { Balb/c mice }\end{array}$ & $\begin{array}{l}\text { i. } \mathrm{g} ., 2 \mathrm{mg} / \mathrm{kg} \text {, once a day for } 5 \\
\text { days, followed by further adminis- } \\
\text { tration once a week for } 44 \text { days }\end{array}$ & blocking the tumor growth and tumor volume & {$[22]$} \\
\hline $\begin{array}{l}95 \% \text { ethanol (vol- } \\
\text { ume, } \mathrm{CH}_{3} \mathrm{CH}_{3} \mathrm{OH} \text { : } \\
\left.\mathrm{H}_{2} \mathrm{O}=95: 5\right) \text { ex- } \\
\text { tracts of licorice }\end{array}$ & $\begin{array}{l}\mathrm{CT} 26 \text { xenografted } \mathrm{BALB} / \mathrm{C} \\
\text { mice }\end{array}$ & $\begin{array}{l}\text { i. g., } 0.5,1 \text {, and } 2 \mathrm{mg} / \mathrm{kg} \text {, once a } \\
\text { day for } 15 \text { days }\end{array}$ & $\begin{array}{l}\text { inhibiting tumor growth by } 38 \%, 57 \% \text {, and } 71 \% \text {, } \\
\text { respectively }\end{array}$ & {$[31]$} \\
\hline \multirow[t]{5}{*}{ Glycyrrhizic acid } & $\begin{array}{l}\text { Renca cells inject s.c. into } \\
\text { BALB/c mice. }\end{array}$ & $\begin{array}{l}\text { i. p., } 50 \mathrm{mg} / \mathrm{kg} \text {, once a day for a } \\
\text { week }\end{array}$ & $\begin{array}{l}\text { supressing } 35 \% \text { of tumor weight and } 60 \% \text { of tumor } \\
\text { volume by reducing angiogenesis }\end{array}$ & {$[46]$} \\
\hline & ovariectomized mice models & $\begin{array}{l}\text { p. o., diet containing } 0.0625 \% \text { wt } \\
\text { of GA, two weeks }\end{array}$ & $\begin{array}{l}\text { GA suppressed the endometrial cancer progress by } \\
\text { inhibiting the expression of COX-2, TNF- } \alpha \text {, and IL- } 1\end{array}$ & {$[63]$} \\
\hline & $\begin{array}{l}\text { acetate-induced hyperproli- } \\
\text { ferative activity in Wistar rats }\end{array}$ & $\begin{array}{l}\text { p.o, } 300 \mathrm{mg} / \mathrm{kg} \text {, once a day for } 5 \\
\text { days before i. p. of acetate }\end{array}$ & inhibition of ODC activity and DNA synthesis & {$[64]$} \\
\hline & A549-bearing mice models & $\begin{array}{l}\text { i. p., } 50 \mathrm{mg} / \mathrm{kg} \text {, once every other } \\
\text { day for } 8 \text { weeks }\end{array}$ & $\begin{array}{l}\text { inhibiting the tumor growth by reduction of TxA2 } \\
\text { expression }\end{array}$ & {$[40]$} \\
\hline & $\begin{array}{l}\text { diethylnitrosamine-induced } \\
\text { hepato tumor of BALB/c mice } \\
\text { models }\end{array}$ & $\begin{array}{l}\text { i. } \mathrm{m} ., 2 \mathrm{mg} / \text { mouse, three times a } \\
\text { week for } 32 \text { weeks }\end{array}$ & $\begin{array}{l}\text { suppression of the mean number of liver tumors } \\
\text { from } 1.64 \text { to } 0.71 \text { and reduction of the incidence } \\
\text { rate of hepatic tumors from } 64 \% \text { to } 21 \%\end{array}$ & {$[67]$} \\
\hline Glycyrrhetinic acid & $\begin{array}{l}\text { SGC7901 xenografted nude } \\
\text { mice }\end{array}$ & $\begin{array}{l}\text { s. c., } 30 \mathrm{mg} / \mathrm{kg} \text {, once every other } \\
\text { day for } 4 \text { weeks }\end{array}$ & $\begin{array}{l}\text { inhibition of tumor tissues growth and induced } \\
\text { apoptosis by decreasing the expression of Bid }\end{array}$ & [71] \\
\hline
\end{tabular}

clear. Thus, we suggest that more high throughput technologies, such as genomics, proteomics, biochip, and high-content screening, may be utilized to promote the explorative speed of the anticancer mechanisms of licorice [187,188]. For example, by utilizing the oligonucleotide microarray analysis to screen 3360 genes after treatment with $0.25 \mu \mathrm{g} / \mathrm{mL}$ tanshinone IIA for $72 \mathrm{~h}$ in MCF7 cells, 41 genes were increased and 24 genes were decreased. Among these genes, the ADP-ribosyltransferase gene exhibited the maximum induction, thus indicating that the gene may be the main target [189]. Besides, through the use of frontal affinity 
Table 2 Continued

\begin{tabular}{|c|c|c|c|c|}
\hline Compounds & Models & Treatments & Outcomes & Ref. \\
\hline \multirow[t]{10}{*}{ Isoliquiritigenin } & $\begin{array}{l}\text { MDA-MB-231 xenografted } \\
\text { nude mice }\end{array}$ & $\begin{array}{l}\text { i. p., } 50 \text { and } 100 \mathrm{mg} / \mathrm{kg} \text {, three } \\
\text { times a week for } 5 \text { weeks }\end{array}$ & $\begin{array}{l}\text { decreasing the tumor weight about } 43.1 \% \text { and } \\
62.3 \% \text {, respectively, with the downregulation of the } \\
\text { intratumoral } \text { PGE }_{2}, 20-\mathrm{HETE} \text {, and p-Akt levels, while } \\
\text { induction of intratumoral cleaved caspase- } 3 \text { and } \\
\text { cleaved PARP levels }\end{array}$ & [111] \\
\hline & $\begin{array}{l}\text { MDA-MB-231 implanted } \\
\text { Balb/c mice }\end{array}$ & $\begin{array}{l}\text { p. } 0 ., 10 \mathrm{mg} / \mathrm{kg}, 5 \text { times a week for } \\
5 \text { weeks }\end{array}$ & $\begin{array}{l}\text { remarkably inhibition of the number of lung surface } \\
\text { metastases with decreasing the intratumoral levels } \\
\text { of MMP- } 2 \text { and MMP-9 }\end{array}$ & {$[131]$} \\
\hline & $\begin{array}{l}\text { U14-implanted Kunming } \\
\text { female mice model }\end{array}$ & $\begin{array}{l}\text { p. } 0 ., 20 \mathrm{mg} / \mathrm{kg} \text {, once a day for } 10 \\
\text { days }\end{array}$ & $\begin{array}{l}\text { inhibiting the tumor weight about } 43.55 \% \text { and en- } \\
\text { hancing the antitumor growth of CP from } 35.57 \% \text { to } \\
65.66 \%\end{array}$ & [102] \\
\hline & $\begin{array}{l}\text { B16-F0 cells (treated or un- } \\
\text { treated with } 15 \mu \mathrm{g} / \mathrm{mL} \text { ISL for } \\
48 \mathrm{~h} \text { ) were inoculated s.c into } \\
\text { C57BL/6 mice }\end{array}$ & 10 days & inhibiting the tumor weight about $29.6 \%$ & {$[123]$} \\
\hline & U266 xenografted SCID mice & i. p., 100 and $200 \mu \mathrm{g} / \mathrm{kg}, 20$ days & $\begin{array}{l}\text { suppressing the tumor volume about } 47.56 \% \text { and } \\
64.55 \% \text {, respectively }\end{array}$ & {$[110]$} \\
\hline & $\begin{array}{l}\text { MPC-11 xenografted } B A B L / C \\
\text { mice }\end{array}$ & i. p., 100 and $200 \mu \mathrm{g} / \mathrm{kg}, 15$ days & $\begin{array}{l}\text { inhibiting the tumor volume about } 82.30 \% \text { and } \\
90.64 \% \text {, respectively }\end{array}$ & {$[110]$} \\
\hline & $\begin{array}{l}\text { ACC-M xenografted BALB/C } \\
\text { nude mice models }\end{array}$ & $\begin{array}{l}\text { p. } 0 ., 0.5 \mathrm{~g} / \mathrm{kg} \text { or } 1 \mathrm{~g} / \mathrm{kg} \text {, daily for } \\
30 \text { consecutive days }\end{array}$ & $\begin{array}{l}\text { inhibiting the tumor growth by induction of the } \\
\text { mTOR-dependent autophagic and apoptosis }\end{array}$ & [132] \\
\hline & $\begin{array}{l}\text { Renca xenografted } B A L B / C \\
\text { male mice models }\end{array}$ & $\begin{array}{l}\text { i. p., } 0.1,0.5,2,10 \mathrm{mg} / \text { day, once a } \\
\text { day for } 10 \text { days }\end{array}$ & $\begin{array}{l}\text { decreasing } 40.59 \%, 45.59 \%, 60.00 \% \text {, and } 68.23 \% \\
\text { of metastatic nodules in lungs, respectively, by sup- } \\
\text { pressing the amount of VEGF and activating the im- } \\
\text { mune system }\end{array}$ & [119] \\
\hline & $\begin{array}{l}\text { CT26 inoculated into BALB/C } \\
\text { mice models, }\end{array}$ & $\begin{array}{l}\text { p. } 0 ., 1 \mathrm{mg} / \mathrm{kg} \text {, once a day for } 15 \\
\text { days }\end{array}$ & $\begin{array}{l}\text { suppressing the } 52 \% \text { of tumors growth, enhancing } \\
\text { the antitumor growth effects of cisplatin, and alle- } \\
\text { viating the cisplatin-induced nephrotoxicity and } \\
\text { hepatotoxicity by blocking the oxidative stress and } \\
\text { intracellular ROS generation }\end{array}$ & [105] \\
\hline & $\begin{array}{l}\text { in the AOM-induced colonic } \\
\text { aberrant crypt focus and } \\
\text { cancer formation of ddY } \\
\text { mice model }\end{array}$ & $\begin{array}{l}\text { p. o., } 15 \text { ppm in drinking water, } 4 \\
\text { weeks }\end{array}$ & $\begin{array}{l}\text { exhibition of } 37.3 \% \text { inhibitory rate of the colonic } \\
\text { aberrant crypt focus and cancer formation }\end{array}$ & [146] \\
\hline \multirow[t]{2}{*}{ Licochalcone A } & $\begin{array}{l}\text { CT26 cells inoculated into } \\
\text { Balb/c mice }\end{array}$ & $\begin{array}{l}\text { p. } 0 ., 1 \mathrm{mg} / \mathrm{kg} \text {, once a day for } 15 \\
\text { days }\end{array}$ & inhibited the growth of tumors by $49 \%$ & {$[150]$} \\
\hline & $\begin{array}{l}\text { AOM/DSS-induced colon } \\
\text { carcinogenesis C57BL/6 } \\
\text { mice }\end{array}$ & $\begin{array}{l}\text { p. } 0 ., 5,15 \text {, and } 30 \mathrm{mg} / \mathrm{kg} \text {, three } \\
\text { times a week for } 46 \text { days }\end{array}$ & $\begin{array}{l}\text { exhibition of } 41 \%, 75 \% \text {, and } 98 \% \text { inhibitory rate in } \\
\text { cancer growth, respectively, and inhibition of the } \\
\text { tumor metastasis with decreasing } \beta \text {-catenin ex- } \\
\text { pression and MMP- } 9 \text { activity in cancer tissue }\end{array}$ & {$[165]$} \\
\hline Licochalcone B & $\begin{array}{l}\text { MB } 49 \text { xenografted } \mathrm{C} 57 \mathrm{BL} / 6 \\
\text { mice model }\end{array}$ & $\begin{array}{l}\text { i. t., } 100 \text { uL of LCB ( } 160 \text { uM) once } \\
\text { every other day for } 23 \text { days }\end{array}$ & $\begin{array}{l}\text { obviously inhibiting the tumor growth by inducing } \\
\text { apoptosis }\end{array}$ & {$[167]$} \\
\hline \multirow[t]{2}{*}{ Liquiritigenin } & H22-bearing mice models & $\begin{array}{l}\text { i. g., } 20 \mathrm{mg} / \mathrm{kg} \text {, once a day for } 15 \\
\text { days }\end{array}$ & $\begin{array}{l}\text { exhibition of } 49.3 \% \text { of tumor growth inhibitory rate, } \\
\text { reduction of the MDA content, and induction of ap- } \\
\text { optosis }\end{array}$ & {$[174]$} \\
\hline & HeLa implanted nude mice & $\begin{array}{l}\text { i. g., } 40 \mathrm{mg} / \mathrm{kg} \text {, once every other } \\
\text { day for } 28 \text { days }\end{array}$ & $\begin{array}{l}\text { exhibition of more than } 50 \% \text { inhibitory rate on the } \\
\text { tumor growth, and inhibition of VEGF and MVD } \\
\text { expressions }\end{array}$ & [173] \\
\hline \multirow[t]{2}{*}{ Isoangustone A } & $\begin{array}{l}\mathrm{PC} 3 \text { xenografted in } \mathrm{BALB} / \mathrm{C} \\
\text { nude mice }\end{array}$ & $\begin{array}{l}\text { i. p. } 5 \mathrm{mg} / \mathrm{kg} \text {, once a day for } 8 \\
\text { weeks }\end{array}$ & $\begin{array}{l}\text { reducing tumor volume and tumor weight about } \\
70.0 \% \text { and } 53.6 \% \text {, respectively, inhibiting about } \\
58 \% \text { of PCNA expression, and inducing G1/S phase } \\
\text { arrest by decreasing p } 27^{\text {kip } 1} \text { expression }\end{array}$ & {$[176]$} \\
\hline & $\begin{array}{l}\text { SK-MEL-28-injected male } \\
\text { BALB/c mice, }\end{array}$ & $\begin{array}{l}\text { i. p., } 2 \text { or } 10 \mathrm{mg} / \mathrm{kg} \text {, once a day for } \\
5 \text { weeks }\end{array}$ & $\begin{array}{l}\text { inhibiting the tumor volume and weight by de- } \\
\text { creasing the expression of PCNA, and inhibiting } \\
\text { PI3 K, MKK4, and MKK } 7 \text { activities without losing } \\
\text { body weight }\end{array}$ & [177] \\
\hline Glabridin & $\begin{array}{l}\text { in SK-Hep-1 xenograft BALB/ } \\
\text { c nude mice }\end{array}$ & i. p., $10 \mathrm{mg} / \mathrm{kg}$, three times a week & $\begin{array}{l}\text { suppressing the tumor growth without statistically } \\
\text { significant changes in body weight }\end{array}$ & {$[180]$} \\
\hline
\end{tabular}

chromatography with mass spectrometry detection, the erythropoietin-producing hepatocellular B2 inhibitor has been successfully identified [190]. Therefore, those research methods can also be performed in the future to study the targets and mechanisms of licorice compounds.
Licorice has been traditionally recognized as a "guide drug" (drugs that enhance the effectiveness and reduce the toxicity of other ingredients) and is added to most traditional and modern prescriptions [15,191]. Basic in vitro and in vivo pharmacological studies indicate that the combined treatment of licorice compounds, 


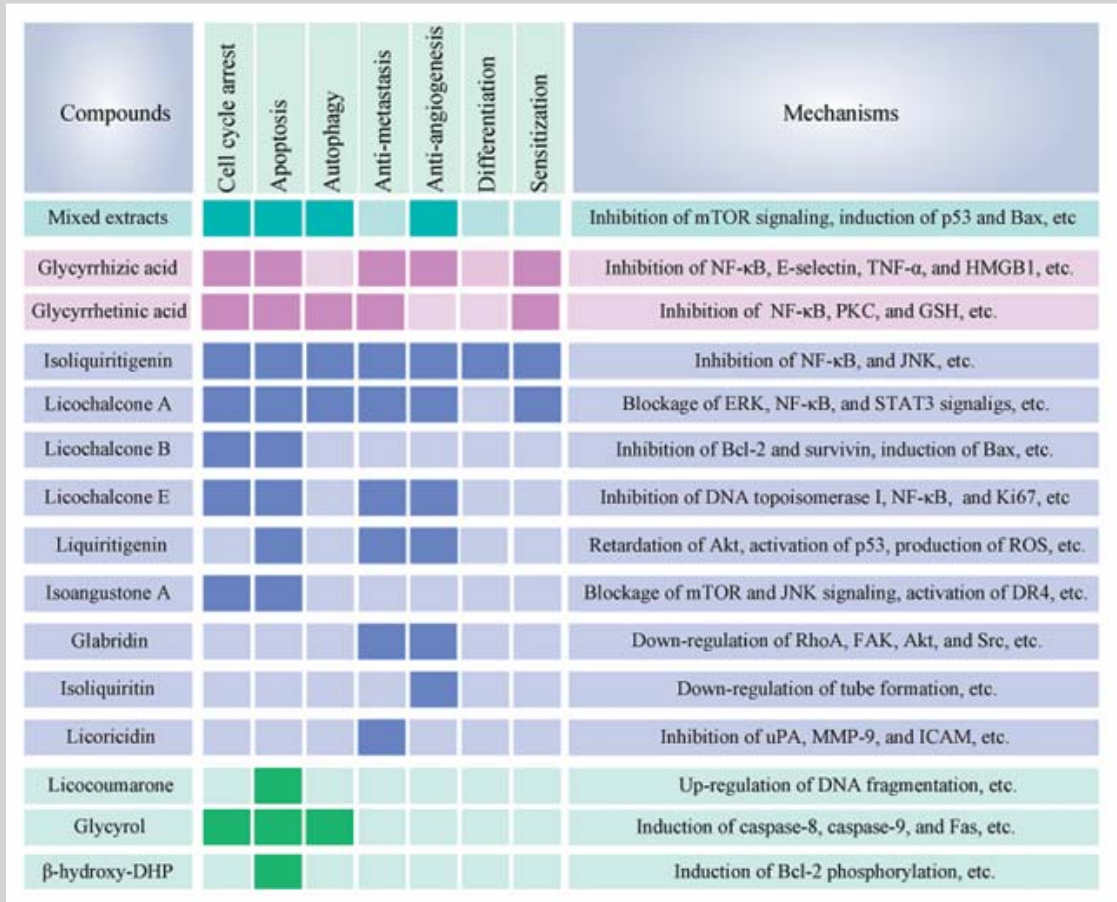

Fig. 2 The anticancer properties and molecular mechanisms of the mixed extracts and purified compounds isolated from licorice. The left panel indicates the anticancer compounds from licorice, the middle panel indicates the impacts of each compound on anticancer studies (the highlighted boxes color means the relevant anticancer effects in the heading have been studied), and the right panel indicates the potential targets or mechanisms contributing to anticancer activities. (Color figure available online only.)

such as GA, ISLG, and LCA, with clinical chemotherapy drugs presents both synergistic antineoplastic effects and a reduction of the side effects of chemotherapeutics [34,102,105, 148]. GL also reverses cisplatin resistance in hepatocellular carcinoma cells [47]. Furthermore, GL pretreatment enhances UVB-induced apoptosis in melanoma cells, blocks UVB-induced skin tumor formation, and hinders ionizing radiation-induced tumor cell extravasation and lung metastasis $[35,49]$. All of these findings indicate that a combined therapy may provide an optimal venue for licorice compounds in clinical application.

Among the purified compounds from licorice, the exploitation of the anticancer effects of GA may be much more compelling. First, GA is of high content and can easily be accessed from licorice with a spectrum of bioactivities $[6,97,192]$. Second, GA has been widely and successfully structure-modified to enhance its anticancer effects and other bioactivities [193-195]. For example, aminoalkyl-modified GA methyl esters successfully yield novel GA derivatives, which exhibit $\mathrm{IC}_{50}$ values between 0.6 and $3.0 \mu \mathrm{M}$ in 14 kinds of cancer cells, while maintaining an $\mathrm{IC}_{50}$ of GA of $80 \mu \mathrm{M}$ in those cancer cells [75]. Furthermore, GA has been widely utilized as a hepatic-targeting ligand in TDDS because of the abundant receptors for GA on the hepatocyte membrane $[32,96]$. Numerous hepatic TDDSs have been developed, such as doxorubicin-loaded GA-modified alginate nanoparticles [96], doxorubicin-loaded GA-modified sulfated chitosan [94], and 5fluorouracil-loaded GA-modified chitosan nanoparticles [93] among others. Those nanoparticles not only enhance the hepatic accumulation of chemotherapeutics to enhance the anticancer effects, but also decrease the side effects.

\section{Acknowledgements}

$\nabla$

We greatly thank Dr. Xi-Wen Li from the Institute of Chinese Materia Medica, China Academy of Chinese Medical Sciences for his useful comments. This work was supported by the Macao Science and Technology Development Fund (074/2012/A3) and the Research Fund of University of Macau (MRG013/WYT/2013/ICMS, CPG2014-00012-ICMS, and MYRG2015-00101-ICMS-QRCM).

\section{Conflict of Interest \\ $\nabla$}

The authors declare that they have no competing interests.

\section{References}

1 Blumenthal M, Goldberg A, Brinckmann J, editors. Herbal medicine: expanded commission E monographs. Boston, MA: Integrative Medicine Communications; 2000

2 Yang S. The Divine Farmer's Materia Medica: A Translation of the Shen Nong Ben Cao Jing. Boulder, CO: Blue Poppy Enterprises, Inc.; 1998

3 Nomura T, Fukai T. Phenolic constituents of licorice (Glycyrrhiza species). In: Herz W, Kirby GW, Moore RE, Steglich W, Tamm C, editors. Fortschritte der Chemie organischer Naturstoffe/Progress in the Chemistry of Organic Natural Products, Vol. 73. Vienna: Springer; 1998: 1140

4 Shibata S. A drug over the millennia: pharmacognosy, chemistry, and pharmacology of licorice. Yakugaku Zasshi 2000; 120: 849-862

5 Fujita T, Sezik E, Tabata M, Yesilada E, Honda G, Takeda Y, Tanaka T, Takaishi $Y$. Traditional medicine in Turkey VII. Folk medicine in middle and west Black Sea regions. Econ Bot 1995; 49: 406-422

6 Asl MN, Hosseinzadeh H. Review of pharmacological effects of Glycyrrhi$z a$ sp. and its bioactive compounds. Phytother Res 2008; 22: 709-724

7 Wang ZY, Nixon DW. Licorice and cancer. Nutr Cancer 2001; 39: 1-11

8 Nomura T, Fukai T, Akiyama T. Chemistry of phenolic compounds of licorice (Glycyrrhiza species) and their estrogenic and cytotoxic activities. Pure Appl Chem 2002; 74: 1199-1206

9 Zhang $Q$ Ye $M$. Chemical analysis of the Chinese herbal medicine GanCao (licorice). J Chromatogr A 2009; 13: 1954-1969

10 Ong ES, Len SM. Pressurized hot water extraction of berberine, baicalein and glycyrrhizin in medicinal plants. Anal Chim Acta 2003; 482: 81-89

11 Li BQ Wang HB, Li XY, Cheng X. Study on combined extraction of flavonoids and glycyrrhizic acid from Glycyrrhiza by using ultrasonic assisted method. SD J Tradit Chin Med 2005; 24: 38-40 
12 Ong ES. Chemical assay of glycyrrhizin in medicinal plants by pressurized liquid extraction (PLE) with capillary zone electrophoresis (CZE). J Sep Sci 2002; 25: 825-831

13 Wang HB, Zhou ZB, Luo F, Yang L. Study on extraction method of flavonoids from Glycyrrhiza and its anti-oxida activity. LSZ Med and Mater Med Res 2008; 19: 2106-2107

14 Cui YM, Yu LJ, Ao MZ, Yang Y, Hu J. Studies on flavonoids extraction technology from Glycyrrhiza inflata and their bacteriostatic activities. J Chin Med Mater 2006; 29: 838-841

15 Commission CP. Pharmacopoeia of the People's Republic of China, Part 1 (2010). Beijing: China Medical Science Press; 2010

16 Shin EM, Kim S, Merfort I, Kim YS. Glycyrol induces apoptosis in human Jurkat T cell lymphocytes via the Fas-FasL/caspase-8 pathway. Planta Med 2011; 77: 242-247

17 Shimizu N, Tomoda M, Takada K, Gonda R. The core structure and immunological activities of glycyrrhizan UA, the main polysaccharide from the root of Glycyrrhiza uralensis. Chem Pharm Bull (Tokyo) 1992; 40: $2125-2128$

18 Yang G, Yu Y. Immunopotentiating effect of traditional Chinese drugsginsenoside and glycyrrhiza polysaccharide. Proc Chin Acad Med Sci Peking Union Med Coll 1990; 5: 188-193

19 Jo EH, Hong HD, Ahn NC, JungJW, Yang SR, ParkJS, Kim SH, Lee YS, Kang KS. Modulations of the Bcl-2/Bax family were involved in the chemopreventive effects of licorice root (Glycyrrhiza uralensis Fisch) in MCF-7 human breast cancer cell. J Agric Food Chem 2004; 52: 1715-1719

20 Popovich DG, Yeo SY, Zhang W. Ginseng (Panax quinquefolius) and licorice (Glycyrrhiza uralensis) root extract combinations increase hepatocarcinoma cell (Hep-G2) viability. Evid Based Complement Alternat Med 2011; 2011: 408273

21 Watanabe M, Hayakawa S, Isemura M, Kumazawa S, Nakayama T, Mori C, Kawakami T. Identification of licocoumarone as an apoptosis-inducing component in licorice. Biol Pharm Bull 2002; 25: 1388-1390

22 Lee SK, Park KK, Park JH, Lim SS, Chung WY. The inhibitory effect of roasted licorice extract on human metastatic breast cancer cell-induced bone destruction. Phytother Res 2013; 27: 1776-1783

23 Yo YT, Shieh GS, Hsu KF, Wu CL, Shiau AL. Licorice and licochalcone-A induce autophagy in LNCaP prostate cancer cells by suppression of Bcl-2 expression and the mTOR pathway. J Agric Food Chem 2009; 57: 82668273

24 Park SY, Kim EJ, Choi HJ, Seon MR, Lim SS, Kang YH, Choi MS, Lee KW, Park Y, Han J. Anti-carcinogenic effects of non-polar components containing licochalcone A in roasted licorice root. Nutr Res Pract 2014; 8 : 257-266

25 Chung WT, Lee SH, Kim JD, Sung NS, Hwang B, Lee SY, Yu CY, Lee HY. Effect of the extracts from Glycyrrhiza uralensis Fisch on the growth characteristics of human cell lines: anti-tumor and immune activation activities. Cytotechnology 2001; 37: 55-64

26 Jo EH, Kim SH, Ra JC, Kim SR, Cho SD, Jung JW, Yang SR, Park JS, Hwang JW, Aruoma OI, Kim TY, Lee YS, Kang KS. Chemopreventive properties of the ethanol extract of chinese licorice (Glycyrrhiza uralensis) root: induction of apoptosis and G1 cell cycle arrest in MCF-7 human breast cancer cells. Cancer Lett 2005; 230: 239-247

27 Seon MR, Park SY, Kwon SJ, Lim SS, Choi HJ, Park H, Lim do Y, Kim JS, Lee CH, Kim J, Park JH. Hexane/ethanol extract of Glycyrrhiza uralensis and its active compound isoangustone A induce G1 cycle arrest in DU145 human prostate and $4 \mathrm{~T} 1$ murine mammary cancer cells. J Nutr Biochem 2012; 23: 85-92

28 Rafi MM, Vastano BC, Zhu N, Ho CT, Ghai G, Rosen RT, Gallo MA, DiPaola $R S$. Novel polyphenol molecule isolated from licorice root (Glycrrhiza glabra) induces apoptosis, G2/M cell cycle arrest, and Bcl-2 phosphorylation in tumor cell lines. J Agric Food Chem 2002; 50: 677-684

29 Seon MR, Lim SS, Choi HJ, Park SY, Cho HJ, Kim JK, Kim J, Kwon DY, Park $J H$. Isoangustone A present in hexane/ethanol extract of Glycyrrhiza uralensis induces apoptosis in DU145 human prostate cancer cells via the activation of DR4 and intrinsic apoptosis pathway. Mol Nutr Food Res 2010; 54: 1329-1339

30 Sheela ML, Ramakrishna MK, Salimath BP. Angiogenic and proliferative effects of the cytokine VEGF in Ehrlich ascites tumor cells is inhibited by Glycyrrhiza glabra. Int Immunopharmacol 2006; 6: 494-498

31 Lee CK, Park KK, Lim SS, Park JH, Chung WY. Effects of the licorice extract against tumor growth and cisplatin-induced toxicity in a mouse xenograft model of colon cancer. Biol Pharm Bull 2007; 30: 2191-2195

32 Negishi M, Irie A, Nagata N, Ichikawa A. Specific binding of glycyrrhetinic acid to the rat liver membrane. Biochim Biophys Acta 1991; 1066: $77-82$
33 Ismair MG, Stanca C, Ha HR, Renner EL, Meier PJ, Kullak-Ublick GA. Interactions of glycyrrhizin with organic anion transporting polypeptides of rat and human liver. Hepatol Res 2003; 26: 343-347

34 Lee CS, Kim YJ, Lee MS, Han ES, Lee SJ. 18ß-Glycyrrhetinic acid induces apoptotic cell death in SiHa cells and exhibits a synergistic effect against antibiotic anti-cancer drug toxicity. Life Sci 2008; 83: 481-489

35 Rossi T, Benassi L, Magnoni C, Ruberto AI, Coppi A, Baggio G. Effects of glycyrrhizin on UVB-irradiated melanoma cells. In Vivo 2005; 19: 319-322

36 Lee J, Jung E, Park J, Jung K, Park E, Kim J, Hong S, Park J, Park S, Lee S, Park $D$. Glycyrrhizin induces melanogenesis by elevating a cAMP level in b16 melanoma cells. J Invest Dermatol 2005; 124: 405-411

37 Chueh FS, Hsiao YT, Chang SJ, Wu PP, Yang JS, Lin JJ, Chung JG, Lai TY. Glycyrrhizic acid induces apoptosis in WEHI-3 mouse leukemia cells through the caspase- and mitochondria-dependent pathways. Oncol Rep 2012; 28: 2069-2076

38 He SQ Gao M, Fu YF, Zhang YN. Glycyrrhizic acid inhibits leukemia cell growth and migration via blocking AKT/mTOR/STAT3 signaling. Int J Clin Exp Pathol 2015; 8: 5175-5181

39 Satomi Y, Nishino H, Shibata S. Glycyrrhetinic acid and related compounds induce G1 arrest and apoptosis in human hepatocellular carcinoma HepG2. Anticancer Res 2005; 25: 4043-4047

40 Huang RY, Chu YL, Jiang ZB, Chen XM, Zhang X, Zeng X. Glycyrrhizin suppresses lung adenocarcinoma cell growth through inhibition of thromboxane synthase. Cell Physiol Biochem 2014; 33: 375-388

$41 \mathrm{Li}$ S, Zhu JH, Cao LP, Sun Q Liu HD, Li JS, Hang CH. Growth inhibitory in vitro effects of glycyrrhizic acid in U251 glioblastoma cell line. Neurol Sci 2014; 35: 1115-1120

42 Thirugnanam S, Xu L, Ramaswamy K, Gnanasekar M. Glycyrrhizin induces apoptosis in prostate cancer cell lines DU-145 and LNCaP. Oncol Rep 2008; 20: 1387-1392

43 Rossi T, Castelli M, Zandomeneghi G, Ruberto A, Benassi L, Magnoni C, Santachiara S, Baggio G. Selectivity of action of glycyrrhizin derivatives on the growth of MCF-7 and HEP-2 cells. Anticancer Res 2003; 23 : 3813-3818

44 Kobayashi M, Fujita K, Katakura T, Utsunomiya T, Pollard RB, Suzuki F. Inhibitory effect of glycyrrhizin on experimental pulmonary metastasis in mice inoculated with B16 melanoma. Anticancer Res 2002; 22 4053-4058

45 Kobayashi S, Miyamoto T, Kimura I, Kimura M. Inhibitory effect of isoliquiritin, a compound in licorice root, on angiogenesis in vivo and tube formation in vitro. Biol Pharm Bull 1995; 18: 1382-1386

$46 \mathrm{Kim}$ KJ, Choi JS, Kim KW, Jeong JW. The anti-angiogenic activities of glycyrrhizic acid in tumor progression. Phytother Res 2013; 27: 841-846

47 Wakamatsu T, Nakahashi Y, Hachimine D, Seki T, Okazaki K. The combination of glycyrrhizin and lamivudine can reverse the cisplatin resistance in hepatocellular carcinoma cells through inhibition of multidrug resistance-associated proteins. Int J Oncol 2007; 31: 1465-1472

48 Sun MF, Chang TT, Chang KW, Huang HJ, Chen HY, Tsai FJ, Lin JG, Chen CY. Blocking the DNA repair system by traditional Chinese medicine? J Biomol Struct Dyn 2011; 28: 895-906

49 Cherng JM, Tsai KD, Yu YW, Lin JC. Molecular mechanisms underlying chemopreventive activities of glycyrrhizic acid against UVB-radiationinduced carcinogenesis in SKH-1 hairless mouse epidermis. Radiat Res 2011; 176: 177-186

50 Palumbo R, Sampaolesi M, De Marchis F, Tonlorenzi R, Colombetti S, Mondino A, Cossu G, Bianchi ME. Extracellular HMGB1, a signal of tissue damage, induces mesoangioblast migration and proliferation. J Cell Biol 2004; 164: 441-449

51 Shotorbani SS, Su ZL, Xu HX. Toll-like receptors are potential therapeutic targets in rheumatoid arthritis. World J Biol Chem 2011; 2: 167-172

52 Smolarczyk R, Cichon T, Matuszczak S, Mitrus I, Lesiak M, Kobusinska M, Kamysz W, Jarosz M, Sieron A, Szala S. The role of Glycyrrhizin, an inhibitor of HMGB1 protein, in anticancer therapy. Arch Immunol Ther Exp (Warsz) 2012; 60: 391-399

53 Schlueter C, Weber H, Meyer B, Rogalla P, Röser K, Hauke S, Bullerdiek J. Angiogenetic signaling through hypoxia: HMGB1: an angiogenetic switch molecule. Am J Pathol 2005; 166: 1259-1263

54 Mollica L, De Marchis F, Spitaleri A, Dallacosta C, Pennacchini D, Zamai M, Agresti A, Trisciuoglio L, Musco G, Bianchi ME. Glycyrrhizin binds to high-mobility group box 1 protein and inhibits its cytokine activities. Chem Biol 2007; 14: 431-441

55 Gong G, Xiang L, Yuan L, Hu L, Wu W, Cai L, Yin L, Dong H. Protective effect of glycyrrhizin, a direct HMGB1 inhibitor, on focal cerebral ische- 
mia/reperfusion-induced inflammation, oxidative stress, and apoptosis in rats. PLoS One 2014; 9: e89450

56 Chung JG, Chang HL, Lin WC, Wang HH, Yeh CC, Hung CF, Li YC. Inhibition of N-acetyltransferase activity and DNA-2-aminofluorene adducts by glycyrrhizic acid in human colon tumour cells. Food Chem Toxicol 2000; 38: 163-172

57 Ilett KF, David BM, Detchon P, Castleden WM, Kwa R. Acetylation phenotype in colorectal carcinoma. Cancer Res 1987; 47: 1466-1469

58 Kirlin WG, Trinidad A, Yerokun T, Ogolla F, Ferguson RJ, Andrews AF, Brady PK, Hein DW. Polymorphic expression of acetyl coenzyme A-dependent arylamine $\mathrm{N}$-acetyltransferase and acetyl coenzyme A-dependent $\mathrm{O}$-acetyltransferase-mediated activation of $\mathrm{N}$-hydroxyarylamines by human bladder cytosol. Cancer Res 1989; 49: 2448-2454

59 Umemura T, Tokumo K, Sirma H, Gebhardt R, Poirier MC, Williams GM. Dose response effects of 2-acetylaminofluorene on DNA damage, cytotoxicity, cell proliferation and neoplastic conversion in rat liver. Cancer Lett 1993; 73: 1-10

60 Shi L, Tang C, Yin C. Glycyrrhizin-modified O-carboxymethyl chitosan nanoparticles as drug vehicles targeting hepatocellular carcinoma. Biomaterials 2012; 33: 7594-7604

61 Lin A, Chen J, Liu Y, Deng S, Wu Z, Huang Y, Ping Q. Preparation and evaluation of N-caproyl chitosan nanoparticles surface modified with glycyrrhizin for hepatocyte targeting. Drug Dev Ind Pharm 2009; 35: 1348-1355

62 Lin A, Liu Y, Huang Y, Sun J, Wu Z, Zhang X, Ping Q. Glycyrrhizin surfacemodified chitosan nanoparticles for hepatocyte-targeted delivery. Int J Pharm 2008; 359: 247-253

63 Niwa K, Lian Z, Onogi K, Yun W, Tang L, Mori H, Tamaya T. Preventive effects of glycyrrhizin on estrogen-related endometrial carcinogenesis in mice. Oncol Rep 2007; 17: 617-622

64 Rahman S, Sultana S. Chemopreventive activity of glycyrrhizin on lead acetate mediated hepatic oxidative stress and its hyperproliferative activity in Wistar rats. Chem Biol Interact 2006; 160: 61-69

65 Rahman S, Sultana S. Glycyrrhizin exhibits potential chemopreventive activity on 12-0-tetradecanoyl phorbol-13-acetate-induced cutaneous oxidative stress and tumor promotion in Swiss albino mice. J Enzyme Inhib Med Chem 2007; 22: 363-369

66 Agarwal $R$, Wang $Z Y$, Mukhtar $H$. Inhibition of mouse skin tumor-initiating activity of DMBA by chronic oral feeding of glycyrrhizin in drinking water. Nutr Cancer 1991; 15: 187-193

67 Shiota G, Harada K, Ishida M, Tomie Y, Okubo M, Katayama S, Ito H, Kawasaki $H$. Inhibition of hepatocellular carcinoma by glycyrrhizin in diethylnitrosamine-treated mice. Carcinogenesis 1999; 20: 59-63

68 Csuk R, Schwarz S, Siewert B, Kluge R, Ströhl D. Synthesis and antitumor activity of ring A modified glycyrrhetinic acid derivatives. Eur J Med Chem 2011; 46: 5356-5369

69 Yang JC, Myung SC, Kim W, Lee CS. 18 $\beta$-Glycyrrhetinic acid potentiates Hsp90 inhibition-induced apoptosis in human epithelial ovarian carcinoma cells via activation of death receptor and mitochondrial pathway. Mol Cell Biochem 2012; 370: 209-219

70 Lee CS, Yang JC, Kim YJ, Jang ER, Kim W, Myung SC. 18Beta-glycyrrhetinic acid potentiates apoptotic effect of trichostatin A on human epithelial ovarian carcinoma cell lines. Eur J Pharmacol 2010; 649: 354-361

71 Lin D, Zhong W, Li J, Zhang B, Song G, Hu T. Involvement of BID translocation in glycyrrhetinic acid and 11-deoxy glycyrrhetinic acid-induced attenuation of gastric cancer growth. Nutr Cancer 2014; 66: 463-473

72 Luo HL, Zhang ZL, Wu QN, Huang MS, Wei H, Zhang DF, Yang F. 18ß-Glycyrrhetinic acid-induced apoptosis and relation with intracellular $\mathrm{Ca} 2+$ release in human breast carcinoma cells. Chinese-German J Clin Oncol 2004; 3: 137-140

73 Song J, Ko HS, Sohn EJ, Kim B, Kim JH, Kim HJ, Kim C, Kim JE, Kim SH. Inhibition of protein kinase $\mathrm{C}$ alpha/betaII and activation of c-Jun $\mathrm{NH} 2$ terminal kinase mediate glycyrrhetinic acid induced apoptosis in nonsmall cell lung cancer NCI-H460 cells. Bioorg Med Chem Lett 2014; 24 : 1188-1191

74 Shetty AV, Thirugnanam S, Dakshinamoorthy G, Samykutty A, Zheng G, Chen A, Bosland MC, Kajdacsy-Balla A, Gnanasekar M. 18alpha-glycyrrhetinic acid targets prostate cancer cells by down-regulating inflammation-related genes. Int J Oncol 2011; 39: 635-640

75 Csuk R, Schwarz S, Kluge R, Ströhl D. Synthesis and biological activity of some antitumor active derivatives from glycyrrhetinic acid. Eur J Med Chem 2010; 45: 5718-5723

76 Lin KW, Huang AM, Hour TC, Yang SC, Pu YS, Lin CN. 18 $\beta$-glycyrrhetinic acid derivatives induced mitochondrial-mediated apoptosis through reactive oxygen species-mediated p53 activation in NTUB1 cells. Bioorg Med Chem 2011; 19: 4274-4285

77 Liu D, Song D, Guo G, Wang R, Lv J, Jing Y, Zhao L. The synthesis of 18beta-glycyrrhetinic acid derivatives which have increased antiproliferative and apoptotic effects in leukemia cells. Bioorg Med Chem 2007; 15: 5432-5439

78 Yu T, Yamaguchi H, Noshita T, Kidachi Y, Umetsu H, Ryoyama K. Selective cytotoxicity of glycyrrhetinic acid against tumorigenic $\mathrm{r} / \mathrm{m} \mathrm{HM}$ SFME-1 cells: potential involvement of $\mathrm{H}$-Ras downregulation. Toxicol Lett 2010; 192: 425-430

79 Yamaguchi H, Yu T, Kidachi Y, Akitaya T, Yoshida K, Kamiie K, Noshita T, Umetsu H, Ryoyama K. Selective toxicity of glycyrrhetinic acid against tumorigenic r/m HM-SFME-1 cells is potentially attributed to downregulation of glutathione. Biochimie 2011; 93: 1172-1178

80 Yamaguchi H, Noshita T, Yu T, Kidachi Y, Kamiie K, Umetsu H, Ryoyama K. Novel effects of glycyrrhetinic acid on the central nervous system tumorigenic progenitor cells: induction of actin disruption and tumor cell-selective toxicity. Eur J Med Chem 2010; 45: 2943-2948

81 Sharma G, Kar S, Palit S, Das PK. 18 $\beta$-Glycyrrhetinic acid induces apoptosis through modulation of Akt/FOXO3a/Bim pathway in human breast cancer MCF-7 cells. J Cell Physiol 2012; 227: 1923-1931

82 Zhu J, Chen M, Chen N, Ma A, Zhu C, Zhao R, Jiang M, Zhou J, Ye L, Fu H, Zhang X. Glycyrrhetinic acid induces G1phase cell cycle arrest in human nonsmall cell lung cancer cells through endoplasmic reticulum stress pathway. Int J Oncol 2015; 46: 981-988

83 Tang ZH, Li T, Chang LL, Zhu H, Tong YG, Chen XP, Wang YT, Lu JJ. Glycyrrhetinic acid triggers a protective autophagy by activation of extracellular regulated protein kinases in hepatocellular carcinoma cells. J Agric Food Chem 2014; 62: 11910-11916

84 Hibasami H, Iwase H, Yoshioka K, Takahashi H. Glycyrrhetic acid (a metabolic substance and aglycon of glycyrrhizin) induces apoptosis in human hepatoma, promyelotic leukemia and stomach cancer cells. Int Mol Med 2006; 17: 215-219

85 Jayasooriya RG, Dilshara MG, Park SR, Choi YH, Hyun JW, Chang WY, Kim GY. $18 \beta$-Glycyrrhetinic acid suppresses TNF- $\alpha$ induced matrix metalloproteinase- 9 and vascular endothelial growth factor by suppressing the Akt-dependent NF- $k$ B pathway. Toxicol In Vitro 2014; 28: 751-758

86 Wang XF, Zhou QM, Lu YY, Zhang H, Huang S, Su SB. Glycyrrhetinic acid potently suppresses breast cancer invasion and metastasis by impairing the p 38 MAPK-AP1 signaling axis. Expert Opin Ther Targets 2015; 19: $577-587$

87 Kitagawa S, Nabekura T, Kamiyama S. Inhibition of P-glycoprotein function by tea catechins in KB-C2 cells. J Pharm Pharmacol 2004; 56: 1001-1005

88 Yamaguchi H, Kidachi Y, Kamiie K, Noshita T, Umetsu H, Ryoyama K. Glycyrrhetinic acid induces anoikis-like death and cytoskeletal disruption in the central nervous system tumorigenic cells. Biol Pharm Bull 2010; 33: $321-324$

89 Huang R, Li M, Hsin M, Underwood M, Ma L, Mok T, Warner T, Chen G. 4Methylnitrosamino-1-3-pyridyl-1-butanone (NNK) promotes lung cancer cell survival by stimulating thromboxane A2 and its receptor. Oncogene 2010; 30: 106-116

90 Kuang P, Zhao W, Su W, Zhang Z, Zhang L, Liu J, Ren G, Yin Z, Wang X. $18 \beta$-Glycyrrhetinic acid inhibits hepatocellular carcinoma development by reversing hepatic stellate cell-mediated immunosuppression in mice. Int J Cancer 2013; 132: 1831-1841

91 Endo S, Matsunaga T, Soda M, Tajima K, Zhao HT, El-Kabbani O, Hara A. Selective inhibition of the tumor marker AKR1B10 by antiinflammatory N-phenylanthranilic acids and glycyrrhetic acid. Biol Pharm Bull 2010; 33: 886-890

92 Zhang C, Wang W, Liu T, Wu Y, Guo H, Wang P, Tian $Q$, Wang Y, Yuan Z. Doxorubicin-loaded glycyrrhetinic acid-modified alginate nanoparticles for liver tumor chemotherapy. Biomaterials 2012; 33: 2187-2196

93 Cheng M, Gao X, Wang Y, Chen H, He B, Xu H, Li Y, Han J, Zhang Z. Synthesis of glycyrrhetinic acid-modified chitosan 5-fluorouracil nanoparticles and its inhibition of liver cancer characteristics in vitro and in vivo. Mar Drugs 2013; 11: 3517-3536

94 Tian $Q$, Wang XH, Wang W, Zhang CN, Wang P, Yuan Z. Self-assembly and liver targeting of sulfated chitosan nanoparticles functionalized with glycyrrhetinic acid. Nanomedicine 2012; 8: 870-879

95 Wang ZY, Agarwal R, Zhou ZC, Bickers DR, Mukhtar H. Inhibition of mutagenicity in Salmonella typhimurium and skin tumor initiating and tumor promoting activities in SENCAR mice by glycyrrhetinic acid: comparison of 18 alpha- and 18 beta-stereoisomers. Carcinogenesis 1991; 12: $187-192$ 
96 Zhang C, Wang W, Liu T, Wu Y, Guo H, Wang P, Tian Q Wang Y, Yuan Z. Doxorubicin-loaded glycyrrhetinic acid-modified alginate nanoparticles for liver tumor chemotherapy. Biomaterials 2012; 33: 21872196

97 Fiore C, Eisenhut M, Krausse R, Ragazzi E, Pellati D, Armanini D, Bielenberg J. Antiviral effects of Glycyrrhiza species. Phytother Res 2008; 22: 141-148

98 Gupta VK, Fatima A, Faridi U, Negi AS, Shanker K, Kumar J, Rahuja N, Luqman S, Sisodia BS, Saikia D. Antimicrobial potential of Glycyrrhiza glabra roots. J Ethnopharmacol 2008; 116: 377-380

99 Hsu YL, Chia CC, Chen PJ, Huang SE, Huang SC, Kuo PL. Shallot and licorice constituent isoliquiritigenin arrests cell cycle progression and induces apoptosis through the induction of ATM/p53 and initiation of the mitochondrial system in human cervical carcinoma HeLa cells. Mol Nutr Food Res 2009; 53: 826-835

100 Yuan X, Zhang B, Chen N, Chen XY, Liu LL, Zheng QS, Wang ZP. Isoliquiritigenin treatment induces apoptosis by increasing intracellular ROS levels in HeLa cells. J Asian Nat Prod Res 2012; 14: 789-798

101 Hirchaud F, Hermetet F, Ablise M, Fauconnet S, Vuitton DA, Pretet JL, Mougin $C$. Isoliquiritigenin induces caspase-dependent apoptosis via downregulation of HPV16 E6 expression in cervical cancer Ca ski cells. Planta Med 2013; 79: 1628-1635

102 Zhao H, Yuan X, Li D, Chen H, Jiang J, Wang Z, Sun X, Zheng Q. Isoliquiritigen enhances the antitumour activity and decreases the genotoxic effect of cyclophosphamide. Molecules 2013; 18: 8786-8798

103 Xiao XY, Hao M, Yang XY, Ba Q Li M, Ni SJ, Wang LS, Du X. Licochalcone A inhibits growth of gastric cancer cells by arresting cell cycle progression and inducing apoptosis. Cancer Lett 2011; 302: 69-75

104 Auyeung KK, Ko JK. Novel herbal flavonoids promote apoptosis but differentially induce cell cycle arrest in human colon cancer cell. Invest New Drugs 2010; 28: 1-13

105 Lee CK, Son SH, Park KK, Park JHY, Lim SS, Chung WY. Isoliquiritigenin inhibits tumor growth and protects the kidney and liver against chemotherapy-induced toxicity in a mouse xenograft model of colon carcinoma. J Pharmacol Sci 2008; 106: 444-451

106 Takahashi T, Takasuka N, Iigo M, Baba M, Nishino H, Tsuda H, Okuyama $T$. Isoliquiritigenin, a flavonoid from licorice, reduces prostaglandin E2 and nitric oxide, causes apoptosis, and suppresses aberrant crypt foci development. Cancer Sci 2004; 95: 448-453

107 Kanazawa M, Satomi Y, Mizutani Y, Ukimura O, Kawauchi A, Sakai T, Baba M, Okuyama T, Nishino H, Miki T. Isoliquiritigenin inhibits the growth of prostate cancer. Eur Urol 2003; 43: 580-586

108 Zhang X, Yeung ED, Wang J, Panzhinskiy EE, Tong C, Li W, Li J. Isoliquiritigenin, a natural anti-oxidant, selectively inhibits the proliferation of prostate cancer cells. Clin Exp Pharmacol Physiol 2010; 37: 841-847

109 Jung JI, Lim SS, Choi HJ, Cho HJ, Shin HK, Kim EJ, Chung WY, Park KK, Park $\mathrm{JH}$. Isoliquiritigenin induces apoptosis by depolarizing mitochondrial membranes in prostate cancer cells. J Nutr Biochem 2006; 17: 689-696

110 Chen X, Wu Y, Jiang Y, Zhou Y, Wang Y, Yao Y, Yi C, Gou L, Yang J. Isoliquiritigenin inhibits the growth of multiple myeloma via blocking IL-6 signaling. J Mol Med (Berl) 2012; 90: 1311-1319

111 Li Y, Zhao H, Wang Y, Zheng H, Yu W, Chai H, Zhang J, Falck JR, Guo AM, Yue J, Peng R, Yang J. Isoliquiritigenin induces growth inhibition and apoptosis through downregulating arachidonic acid metabolic network and the deactivation of PI3 K/Akt in human breast cancer. Toxicol Appl Pharmacol 2013; 272: 37-48

112 Wang KL, Hsia SM, Chan CJ, Chang FY, Huang CY, Bau DT, Wang PS. Inhibitory effects of isoliquiritigenin on the migration and invasion of human breast cancer cells. Expert Opin Ther Targets 2013; 17: 337349

113 Li D, Wang Z, Chen H, Wang J, Zheng Q Shang J, Li J. Isoliquiritigenin induces monocytic differentiation of HL-60 cells. Free Radic Biol Med 2009; 46: 731-736

114 Ii T, Satomi Y, Katoh D, Shimada J, Baba M, Okuyama T, Nishino H, Kitamura $N$. Induction of cell cycle arrest and p21(CIP1/WAF1) expression in human lung cancer cells by isoliquiritigenin. Cancer Lett 2004; 207: 27-35

115 Hsu YL, Kuo PL, Chiang LC, Lin CC. Isoliquiritigenin inhibits the proliferation and induces the apoptosis of human non-small cell lung cancer a549 cells. Clin Exp Pharmacol Physiol 2004; 31: 414-418

116 Jung SK, Lee MH, Lim do Y, Kim JE, Singh P, Lee SY, Jeong CH, Lim TG, Chen H, Chi YI, Kundu JK, Lee NH, Lee CC, Cho YY, Bode AM, Lee KW, Dong $Z$. Isoliquiritigenin induces apoptosis and inhibits xenograft tumor growth of human lung cancer cells by targeting both wild type and L858R/T790 M mutant EGFR. J Biol Chem 2014; 289: 3583935848

117 Yuan X, Yu B, Wang Y, Jiang J, Liu L, Zhao H, Qi W, Zheng Q. Involvement of endoplasmic reticulum stress in isoliquiritigenin-induced SKOV-3 cell apoptosis. Recent Pat Anticancer Drug Discov 2013; 8: 191-199

118 Zhou GS, Song LJ, Yang B. Isoliquiritigenin inhibits proliferation and induces apoptosis of U87 human glioma cells in vitro. Mol Med Rep 2013; 7: 531-536

119 Yamazaki S, Morita T, Endo H, Hamamoto T, Baba M, Joichi Y, Kaneko S, Okada Y, Okuyama T, Nishino H, Tokue A. Isoliquiritigenin suppresses pulmonary metastasis of mouse renal cell carcinoma. Cancer Lett 2002; 183: 23-30

120 Sun C, Zhang H, Ma XF, Zhou X, Gan L, Liu YY, Wang ZH. Isoliquiritigenin enhances radiosensitivity of HepG2 cells via disturbance of redox status. Cell Biochem Biophys 2013; 65: 433-444

$121 \mathrm{Hsu}$ YL, Kuo PL, Lin LT, Lin CC. Isoliquiritigenin inhibits cell proliferation and induces apoptosis in human hepatoma cells. Planta Med 2005; 71: 130-134

122 Hsu YL, Kuo PL, Lin CC. Isoliquiritigenin induces apoptosis and cell cycle arrest through p53-dependent pathway in Hep G2 cells. Life Sci 2005; 77: 279-292

123 Chen X, Zhang B, Yuan X, Yang F, Liu J, Zhao H, Liu L, Wang Y, Wang Z, Zheng $Q$. Isoliquiritigenin-induced differentiation in mouse melanoma B16F0 cell line. Oxid Med Cell Longev 2012; 12: 1-12

124 Chowdhury SA, Kishino K, Satoh R, Hashimoto K, Kikuchi H, Nishikawa $H$, Shirataki $Y$, Sakagami $H$. Tumor-specificity and apoptosis-inducing activity of stilbenes and flavonoids. Anticancer Res 2005; 25: 20552063

125 Kim DC, Ramachandran S, Baek SH, Kwon SH, Kwon KY, Cha SD, Bae I, Cho $\mathrm{CH}$. Induction of growth inhibition and apoptosis in human uterine leiomyoma cells by isoliquiritigenin. Reprod Sci 2008; 15: 552 558

126 Park I, Park KK, Park JHY, Chung WY. Isoliquiritigenin induces G2 and $M$ phase arrest by inducing DNA damage and by inhibiting the metaphase/anaphase transition. Cancer Lett 2009; 277: 174-181

127 Lee CS, Kim YJ, Lee MS, Han ES, Lee SJ. 18Beta-glycyrrhetinic acid induces apoptotic cell death in SiHa cells and exhibits a synergistic effect against antibiotic anti-cancer drug toxicity. Life Sci 2008; 83: 481489

128 Lee YM, Lim do Y, Choi HJ, Jung JI, Chung WY, Park JH. Induction of cell cycle arrest in prostate cancer cells by the dietary compound isoliquiritigenin. J Med Food 2009; 12: 8-14

129 Takahashi T, Baba M, Nishino H, Okuyama T. Cyclooxygenase-2 plays a suppressive role for induction of apoptosis in isoliquiritigenin-treated mouse colon cancer cells. Cancer Lett 2006; 231: 319-325

130 Yoshida T, Horinaka M, Takara M, Tsuchihashi M, Mukai N, Wakada M, Sakai T. Combination of isoliquiritigenin and tumor necrosis factorrelated apoptosis-inducing ligand induces apoptosis in colon cancer HT29 cells. Environ Health Prev Med 2008; 13: 281-287

131 Zheng H, Li Y, Wang Y, Zhao H, Zhang J, Chai H, Tang T, Yue J, Guo AM, Yang J. Downregulation of COX-2 and CYP 4 A signaling by isoliquiritigenin inhibits human breast cancer metastasis through preventing anoikis-resistance, migration and invasion. Toxicol Appl Pharmacol 2014: $280: 10-20$

132 Chen G, Hu X, Zhang W, Xu N, Wang FQ Jia J, Zhang WF, Sun ZJ, Zhao YF Mammalian target of rapamycin regulates isoliquiritigenin-induced autophagic and apoptotic cell death in adenoid cystic carcinoma cells. Apoptosis 2012; 17: 90-101

$133 \mathrm{Ma}$ J, Fu NY, Pang DB, Wu WY, Xu AL. Apoptosis induced by isoliquiritigenin in human gastric cancer MGC-803 cells. Planta Med 2001; 67: 754-757

134 Iwashita K, Kobori M, Yamaki K, Tsushida T. Flavonoids inhibit cell growth and induce apoptosis in B16 melanoma 4A5 cells. Biosci Biotechnol Biochem 2000; 64: 1813-1820

135 Chen H, Zhang B, Yao Y, Chen N, Chen X, Tian H, Wang Z, Zheng Q. $\mathrm{NADPH}$ oxidase-derived reactive oxygen species are involved in the HL-60 cell monocytic differentiation induced by isoliquiritigenin. Molecules 2012; 17: 13424-13438

136 Kwon GT, Cho HJ, Chung WY, Park KK, Moon A, Park JH. Isoliquiritigenin inhibits migration and invasion of prostate cancer cells: possible mediation by decreased JNK/AP-1 signaling. J Nutr Biochem 2009; 20: 663-676

137 Kumar S, Sharma A, Madan B, Singhal V, Ghosh B. Isoliquiritigenin inhibits IkappaB kinase activity and ROS generation to block TNF-alpha 
induced expression of cell adhesion molecules on human endothelial cells. Biochem Pharmacol 2007; 73: 1602-1612

138 Kwon HM, Choi YJ, Choi JS, Kang SW, Bae JY, Kang IJ, Jun JG, Lee SS, Lim SS, Kang YH. Blockade of cytokine-induced endothelial cell adhesion molecule expression by licorice isoliquiritigenin through NF-kappaB signal disruption. Exp Biol Med 2007; 232: 235-245

139 Kimura M, Kimura I, Luo B, Kobayashi S. Antiinflammatory effect of Japanese-Sino medicine 'Keishi-ka-jutsubu-to'and its component drugs on adjuvant air pouch granuloma of mice. Phytother Res 1991; 5: $195-200$

140 Kang SW, Choi JS, Choi YJ, Bae JY, Li J, Kim DS, Kim JL, Shin SY, Lee YJ, Kwun IS, Kang YH. Licorice isoliquiritigenin dampens angiogenic activity via inhibition of MAPK-responsive signaling pathways leading to induction of matrix metalloproteinases. J Nutr Biochem 2010; 21: $55-65$

141 Lee KM, Abel J, Ko Y, Harth V, Park WY, Seo JS, Yoo KY, Choi JY, Shin A, Ahn SH. Genetic polymorphisms of cytochrome P450 19 and 1B1, alcohol use, and breast cancer risk in Korean women. Br J Cancer 2003; 88: 675-678

142 Ye L, Gho WM, Chan FL, Chen S, Leung LK. Dietary administration of the licorice flavonoid isoliquiritigenin deters the growth of MCF-7 cells overexpressing aromatase. Int J Cancer 2009; 124: 1028-1036

143 Wong TY, Lin SM, Poon CH, Leung LK. The licorice flavonoid isoliquiritigenin reduces DNA-binding activity of AhR in MCF-7 cells. Chem Biol Interact 2014; 221: 70-76

144 Wang N, Wang Z, Wang Y, Xie X, Shen J, Peng C, You J, Peng F, Tang H, Guan $X$, Chen J. Dietary compound isoliquiritigenin prevents mammary carcinogenesis by inhibiting breast cancer stem cells through WIF1 demethylation. Oncotarget 2015; 6: 9854-9876

145 Jung JI, Chung E, Seon MR, Shin HK, Kim EJ, Lim SS, Chung WY, Park KK, ParkJH. Isoliquiritigenin (ISL) inhibits ErbB3 signaling in prostate cancer cells. Biofactors 2006; 28: 159-168

146 Baba M, Asano R, Takigami I, Takahashi T, Ohmura M, Okada Y, Sugimoto H, Arika T, Nishino H, Okuyama T. Studies on cancer chemoprevention by traditional folk medicines XXV. Inhibitory effect of isoliquiritigenin on azoxymethane-induced murine colon aberrant crypt focus formation and carcinogenesis. Biol Pharm Bull 2002; 25: 247-250

147 Choi AY, Choi JH, Hwang KY, Jeong YJ, Choe W, Yoon KS, Ha J, Kim SS, Youn JH, Yeo EJ, Kang I. Licochalcone A induces apoptosis through endoplasmic reticulum stress via a phospholipase Cgamma1-, Ca-, and reactive oxygen species-dependent pathway in HepG2 human hepatocellular carcinoma cells. Apoptosis 2013; 19: 682-697

148 Szliszka E, Czuba ZP, Mazur B, Sedek L, Paradysz A, Krol W. Chalcones enhance TRAIL-induced apoptosis in prostate cancer cells. Int J Mol Sci 2009; 11: 1-13

149 Fu Y, Hsieh TC, Guo J, Kunicki J, Lee MY, Darzynkiewicz Z, Wu JM. Licochalcone-A, a novel flavonoid isolated from licorice root (Glycyrrhiza glabra), causes G2 and late-G1 arrests in androgen-independent PC-3 prostate cancer cells. Biochem Biophys Res Commun 2004; 322: 263270

150 Lee CK, Son SH, Park KK, Park JHY, Lim SS, Kim SH, Chung WY. Licochalcone A inhibits the growth of colon carcinoma and attenuates cisplatin-induced toxicity without a loss of chemotherapeutic efficacy in mice. Basic Clin Pharmacol Toxicol 2008; 103: 48-54

151 Yoon G, Kang BY, Cheon SH. Topoisomerase I inhibition and cytotoxicity of licochalcones A and E from Glycyrrhiza inflata. Arch Pharm Res 2007; 30: 313-316

152 Lee CS, Kwak SW, Kim YJ, Lee SA, Park ES, Myung SC, Kim W, Lee MS, Lee $\mathrm{JJ}$. Guanylate cyclase activator YC-1 potentiates apoptotic effect of licochalcone A on human epithelial ovarian carcinoma cells via activation of death receptor and mitochondrial pathways. Eur J Pharmacol 2012; 683: 54-62

153 Szliszka E, Jaworska D, Ksek M, Czuba ZP, Król W. Targeting death receptor TRAIL-R2 by chalcones for TRAIL-induced apoptosis in cancer cells. Int J Mol Sci 2012; 13: 15343-15359

154 Jiang J, Yuan X, Zhao H, Yan X, Sun X, Zheng Q. Licochalcone A inhibiting proliferation of bladder cancer T24 cells by inducing reactive oxygen species production. Biomed Mater Eng 2014; 24: 1019-1025

155 Yuan X, Li D, Zhao H, JiangJ, Wang P, Ma X, Sun X, Zheng Q. Licochalcone A-induced human bladder cancer T24 cells apoptosis triggered by mitochondria dysfunction and endoplasmic reticulum stress. Biomed Res Int 2013; 2013: 474272

156 Cho JJ, Chae JI, Yoon G, Kim KH, Cho JH, Cho SS, Cho YS, Shim JH. Licochalcone A, a natural chalconoid isolated from Glycyrrhiza inflata root, induces apoptosis via Sp1 and Sp1 regulatory proteins in oral squamous cell carcinoma. Int J Oncol 2014; 45: 667-674

157 Hao W, Yuan X, Yu L, Gao C, Sun X, Wang D, Zheng Q. Licochalcone Ainduced human gastric cancer BGC-823 cells apoptosis by regulating ROS-mediated MAPKs and PI3 K/AKT signaling pathways. Sci Rep 2015; 5: $1-8$

158 Kim JS, Park MR, Lee SY, Kim do K, Moon SM, Kim CS, Cho SS, Yoon G, Im HJ, You JS, Oh JS, Kim SG. Licochalcone A induces apoptosis in KB human oral cancer cells via a caspase-dependent FasL signaling pathway. Oncol Rep 2014; 31: 755-762

159 Park JH, Lim HJ, Lee KS, Lee S, Kwak HJ, Cha JH, Park HY. Anti-proliferative effect of licochalcone $A$ on vascular smooth muscle cells. Biol Pharm Bull 2008; 31: 1996-2000

160 Rafi MM, Rosen RT, Vassil A, Ho CT, Zhang H, Ghai G, Lambert G, DiPaola $R S$. Modulation of bcl-2 and cytotoxicity by licochalcone-A, a novel estrogenic flavonoid. Anticancer Res 1999; 20: 2653-2658

161 Shen H, Zeng G, Tang G, Cai X, Bi L, Huang C, Yang Y. Antimetastatic effects of licochalcone A on oral cancer via regulating metastasis-associated proteases. Tumour Biol 2014; 35: 1-8

162 Kim YH, Shin EK, Kim DH, Lee HH, Park JHY, Kim JK. Antiangiogenic effect of licochalcone A. Biochem Pharmacol 2010; 80: 1152-1159

163 Kim YJ, Jung EB, Myung SC, Kim W, Lee CS. Licochalcone A enhances geldanamycin-induced apoptosis through reactive oxygen speciesmediated caspase activation. Pharmacology 2013; 92: 49-59

164 Funakoshi-Tago M, Tago K, Nishizawa C, Takahashi K, Mashino T, Iwata $S$, Inoue H, Sonoda Y, Kasahara T. Licochalcone A is a potent inhibitor of TEL-Jak2-mediated transformation through the specific inhibition of Stat3 activation. Biochem Pharmacol 2008; 76: 1681-1693

165 Kim JK, Shin EK, Park JH, Kim YH, Park JHY. Antitumor and antimetastatic effects of licochalcone A in mouse models. J Mol Med (Berl) 2010; 88: 829-838

166 Shibata S, Inoue H, Iwata S, Ma RD, Yu LJ, Ueyama H, Takayasu J, Hasegawa T, Tokuda H, Nishino A, Nishino H, Iwashima A. Inhibitory effects of licochalcone A isolated from Glycyrrhiza inflata root on inflammatory ear edema and tumour promotion in mice. Planta Med 1991; 57: 221-224

167 Yuan X, Li T, Xiao E, Zhao H, Li Y, Fu S, Gan L, Wang Z, Zheng Q. Licochalcone B inhibits growth of bladder cancer cells by arresting cell cycle progression and inducing apoptosis. Food Chem Toxicol 2014; 65: 242-251

168 Chang HJ, Yoon G, Park JS, Kim MH, Baek MK, Kim NH, Shin BA, Ahn BW Cheon SH, Jung YD. Induction of apoptosis by the licochalcone $\mathrm{E}$ in endothelial cells via modulation of NF-kappaB and Bcl-2 Family. Biol Pharm Bull 2007; 30: 2290-2293

169 Kwon SJ, Park SY, Kwon GT, Lee KW, Kang YH, Choi MS, Yun JW, Jeon JH, Jun JG, Park JH. Licochalcone E present in licorice suppresses lung metastasis in the 4T1 mammary orthotopic cancer model. Cancer Prev Res 2013; 6: 603-613

170 Zhang SP, Zhou YJ, Liu Y, Cai YQ. Effect of liquiritigenin, a flavanone existed from Radix Glycyrrhizae on pro-apoptotic in SMMC-7721 cells. Food Chem Toxicol 2009; 47: 693-701

171 Liu C, Wang Y, Xie S, Zhou Y, Ren X, Li X, Cai Y. Liquiritigenin induces mitochondria-mediated apoptosis via cytochrome $\mathrm{c}$ release and caspases activation in HeLa Cells. Phytother Res 2011; 25: 277-283

172 Wang Y, Xie S, Liu C, Wu Y, Liu Y, Cai Y. Inhibitory effect of liquiritigenin on migration via downregulation proMMP-2 and PI3 K/Akt signaling pathway in human lung adenocarcinoma A549 cells. Nutr Cancer 2012; 64: 627-634

173 Liu Y, Xie S, Wang Y, Luo K, Wang Y, Cai Y. Liquiritigenin inhibits tumor growth and vascularization in a mouse model of HeLa cells. Molecules 2012; 17: 7206-7216

174 Zhou M, Higo H, Cai Y. Inhibition of hepatoma 22 tumor by liquiritigenin. Phytother Res 2010; 24: 827-833

175 Huang W, Tang S, Qiao X, Ma W, Ji S, Wang K, Ye M, Yu S. Isoangustone A induces apoptosis in SW480 human colorectal adenocarcinoma cells by disrupting mitochondrial functions. Fitoterapia 2014; 30: 36-47

176 Lee E, Son JE, Byun S, Lee SJ, Kim YA, Liu K, Kim J, Lim SS, Park JH, Dong Z, Lee KW, Lee HJ. CDK2 and mTOR are direct molecular targets of isoangustone $A$ in the suppression of human prostate cancer cell growth. Toxicol Appl Pharmacol 2013; 272: 12-20

177 Song NR, Lee E, Byun S, Kim JE, Mottamal M, Park JH, Lim SS, Bode AM, Lee HJ, Lee KW, Dong Z. Isoangustone A, a novel licorice compound, inhibits cell proliferation by targeting PI3 K, MKK4, and MKK7 in human melanoma. Cancer Prev Res 2013; 6: 1293-1303 
178 Tsai YM, Yang CJ, Hsu YL, Wu LY, Tsai YC, Hung JY, Lien CT, Huang MS, Kuo PL. Glabridin inhibits migration, invasion, and angiogenesis of human non-small cell lung cancer A549 cells by inhibiting the FAK/rho signaling pathway. Integr Cancer Ther 2011; 10: 341-349

179 Hsu YL, Wu LY, Hou MF, Tsai EM, Lee JN, Liang HL, Jong YJ, Hung CH, Kuo $P L$. Glabridin, an isoflavan from licorice root, inhibits migration, invasion and angiogenesis of MDA-MB-231 human breast adenocarcinoma cells by inhibiting focal adhesion kinase/Rho signaling pathway. Mol Nutr Food Res 2011; 55: 318-327

180 Hsieh MJ, Lin CW, Yang SF, Chen MK, Chiou HL. Glabridin inhibits migration and invasion by transcriptional inhibition of matrix metalloproteinase 9 through modulation of NF-kappaB and AP-1 activity in human liver cancer cells. Br J Pharmacol 2014; 171: 3037-3050

181 Veratti E, Rossi T, Giudice S, Benassi L, Bertazzoni G, Morini D, Azzoni P, Bruni E, Giannetti A, Magnoni C. 18Beta-glycyrrhetinic acid and glabridin prevent oxidative DNA fragmentation in UVB-irradiated human keratinocyte cultures. Anticancer Res 2011; 31: 2209-2215

182 Park SY, Lim SS, Kim JK, Kang IJ, Kim JS, Lee C, Kim J, Park JH. Hexaneethanol extract of Glycyrrhiza uralensis containing licoricidin inhibits the metastatic capacity of DU145 human prostate cancer cells. Br J Nutr 2010; 104: 1272-1282

183 Zhou B, Zhang J, Wu S, Zhuo Q Gao W, Hao J, Man S. The influence of compatibility of processed Radix Aconiti Kusnezoffii on the pharmacokinetic of four components in Glycyrrhiza uralensis Fisch. J Ethnopharmacol 2015; 169: 1-7

184 Lee YK, Chin YW, Bae JK, Seo JS, Choi YH. Pharmacokinetics of isoliquiritigenin and its metabolites in rats: low bioavailability is primarily due to the hepatic and intestinal metabolism. Planta Med 2013; 79: $1656-1665$

185 Kang HE, Jung HY, Cho YK, Kim SH, Sohn SI, Baek SR, Lee MG. Pharmacokinetics of liquiritigenin in mice, rats, rabbits, and dogs, and animal scale-up. J Pharm Sci 2009; 98: 4327-4342

186 Wu YP, Meng XS, Bao YR, Wang S. Pharmacokinetic study of four flavones of Glycyrrhiza in rat plasma using HPLC-MS.J Ethnopharmacol 2013; 148: 266-270
187 Dudgeon DD, Shinde S, Hua Y, Shun TY, Lazo JS, Strock CJ, Giuliano KA, Taylor DL, Johnston PA, Johnston PA. Implementation of a 220,000 compound HCS campaign to identify disruptors of the interaction between p53 and hDM2 and characterization of the confirmed hits. J Biomol Screen 2010; 15: 766-782

188 Youns M, Efferth T, Reichling J, Fellenberg K, Bauer A, Hoheisel JD. Gene expression profiling identifies novel key players involved in the cytotoxic effect of Artesunate on pancreatic cancer cells. Biochem Pharmacol 2009; 78: 273-283

189 Wang X, Wei Y, Yuan S, Liu G, Lu Y, Zhang J, Wang W. Potential anticancer activity of tanshinone IIA against human breast cancer. Int J Cancer 2005; 116: 799-807

190 Toledo-Sherman L, Deretey E, Slon-Usakiewicz JJ, Ng W, Dai JR, Foster JE, Redden PR, Uger MD, Liao LC, Pasternak A, Reid N. Frontal affinity chromatography with MS detection of EphB2 tyrosine kinase receptor. 2. Identification of small-molecule inhibitors via coupling with virtual screening. J Med Chem 2005; 48: 3221-3230

191 Wang X, Zhang H, Chen L, Shan L, Fan G, Gao X. Liquorice, a unique "guide drug" of traditional Chinese medicine: a review of its role in drug interactions. J Ethnopharmacol 2013; 150: 781-790

192 Lauren DR, Jensen DJ, Douglas JA, Follett JM. Efficient method for determining the glycyrrhizin content of fresh and dried roots, and root extracts, of Glycyrrhiza species. Phytochem Anal 2001; 12: 332-335

193 Pang X, Zhang L, Wu Y, Lin L, Li J, Qu W, Safe S, Liu M. Methyl 2-cyano-3, 11-dioxo-18-olean-1, 12-dien-30-oate (CDODA-Me), a derivative of glycyrrhetinic acid, functions as a potent angiogenesis inhibitor. J Pharmacol Exp Ther 2010; 335: 172-179

194 Logashenko EB, Salomatina OV, Markov A, Korchagina DV, Salakhutdinov NF, Tolstikov GA, Vlassov VV, Zenkova MA. Synthesis and pro-apoptotic activity of novel glycyrrhetinic acid derivatives. Chembiochem 2011; 12: 784-794

195 Salomatina OV, Markov AV, Logashenko EB, Korchagina DV, Zenkova MA, Salakhutdinov NF, Vlassov VV, Tolstikov GA. Synthesis of novel 2cyano substituted glycyrrhetinic acid derivatives as inhibitors of cancer cells growth and NO production in LPS-activated J-774 cells. Bioorg Med Chem 2014; 22: 585-593 